\title{
Impact of Border Barriers, Returning Migrants, and Trade Diversion in Brexit: Firm Exit and Loss of Variety
}

\author{
Nobuhiro Hosoe
}

June 2017

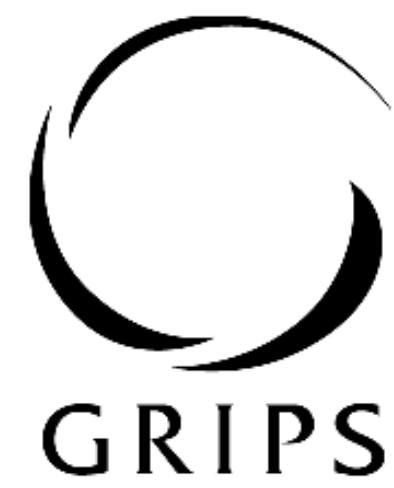

National Graduate institute FOR POLICY STUDIES

National Graduate Institute for Policy Studies

7-22-1 Roppongi, Minato-ku,

Tokyo, Japan 106-8677 


\title{
Impact of Border Barriers, Returning Migrants, and Trade Diversion in Brexit: Firm Exit and Loss of Variety
}

June 20, 2017

National Graduate Institute for Policy Studies

Nobuhiro Hosoe*

\begin{abstract}
We investigate the impact of Brexit (the UK's planned withdrawal from the European Union) using computable general equilibrium models featuring conventional constant returns-to-scale (CRS) and increasing returns-to-scale (IRS) technology and firm heterogeneity, à la Melitz. We show that the imposition of the tariff and nontariff barriers associated with Brexit triggers the significant contraction of bilateral trade between the UK and the remaining 27 members of the European Union (EU27), exacerbated by firm exit from export markets. Given the imposition of these trade barriers, budget savings, migrants returning to the EU27 from the UK, and intra-EU27 integration and free trade agreements with the US and Japan, the IRS model predicts a total export loss of $5.1-5.8 \%$ of UK GDP and a total welfare loss of $1.1-1.5 \%$. This is $60 \%$ greater than the CRS model predictions. However, the impact on output would vary between industries, whereby the UK chemical and automobile industries would contract, but its food, business services, and information and communication technology industries would expand. In contrast, the EU27 would gain substantially from other integration programs, but lose very little from the stronger UKEU27 border barriers. This suggests that the EU27 should have little interest in negotiations aimed at avoiding a "hard Brexit" (the surrendering by the UK of full access to the single market) and that it would be more productive for it to focus on integration programs with trade partners other than the UK.
\end{abstract}

\section{Keywords}

Brexit; Computable General Equilibrium Analysis; Firm Heterogeneity; Nontariff Barriers; Immigration JEL Classification: F13, F17, C63, J61

* 7-22-1 Roppongi, Minato, Tokyo 106-8677, Japan. E-mail: nhosoe@grips.ac.jp. 


\section{Introduction}

The internal market of the European Union (EU) has grown continuously by progressively accepting new member countries, with Croatia in 2013 being the 28th country to join. On June 23, 2016, the results of the referendum for the withdrawal of the United Kingdom (UK) from the EU known as Brexit shook the EU, which has managed to maintain regional cohesion, even following the recent European sovereign debt crisis. Nonetheless, Brexit creates many uncertainties regarding the future of Europe. These include the shortand long-run impacts of new tariff and nontariff barriers (NTBs) between the UK and the remaining 27 members of the EU (EU27), the effect on the common agricultural policy (CAP), changes in regulatory policy and standards, and the influence on foreign direct investment (FDI). The UK contributions to the EU budget are also significant and require consideration (HM Treasury 2013; Núñez Ferrer and Rinaldi 2016).

Immediately before the referendum, many economic studies quantitatively assessed the impact of Brexit employing structural general equilibrium models, especially computable general equilibrium (CGE) models and new quantitative trade models (NQTMs) to predict its possible consequences. For the most part, these analyses attempted to analyze the impact of Brexit using a theoretical framework because suitable empirical data was not available given Brexit has not yet taken place. Accordingly, given the wide range of future event scenarios, even when similar frameworks are used, the estimates of the macroeconomic effects on the UK differ. Overall, most studies estimate a moderate decline, "...in the low single-digit percentage range" in terms of UK GDP, as surveyed by Busch and Matthes (2016). For example, using a GTAP-based world trade dynamic CGE model, Booth et al. (2015) estimated a worst-case reduction in UK GDP of $2.2 \%$ by 2030 , combining the losses associated with tariff imposition $(0.9 \%)$, border costs $(1.2 \%)$, and NTBs on goods $(0.5 \%)$ and services 
(0.1\%), but a saving to its EU budget contribution of $0.5 \% .^{1}$

Elsewhere, Boulanger and Philippidis (2015) used a world trade CGE model calibrated to the GTAP Database and estimated an income effect for 2020. They found that a $2 \%$ trade cost rise would almost cancel out the benefit of the EU budget saving and that a $5 \%$ rise would lead to a $0.7 \%$ loss in terms of UK GDP. ${ }^{2}$ PwC (2016), using a single-country dynamic CGE model, estimated a total loss of $1.2-5.5 \%$ of UK GDP, through anticipated losses via trade-related barriers $(0.5-2.1 \%)$, short-run uncertainty in capital markets $(0.9-$ 2.6\%), and migration (0.8-1.6\%). Lastly, using an NQTM, Dhingra et al. (2017) estimated a total welfare loss of $1.3-2.7 \%$, attributed to the loss from the UK's most favored nation (MFN) tariff imposition (0.1\%), the UK-EU27 NTBs (0.5-1.3\%), and intra-EU27 integration (0.91.6\%). OECD (2016) predicted similar losses to UK GDP.

Unfortunately, most of these studies focused on just a few aggregate outcome variables such as the changes in GDP or net household expenditure, i.e., Hicksian equivalent variations $(\mathrm{EVs})$, and thus did not analyze the possible sectoral output and trade changes in detail, even though their multisector models were well capable of such analysis. This was likely for convenience and the simplicity of presentation for Brexit voters. Moreover, few of the CGE studies, unlike the NQTMs, considered the heterogeneity of firms and increasing returns-to-scale with a love of variety à la Melitz (2003), recently recognized as a key driver of the explosion of trade in the globalized world economy. ${ }^{3}$ For instance, Brexit should restore

\footnotetext{
1 CGE studies prior to the Brexit referendum used the GTAP Database Version 8 with a reference year of 2007, which is one version older than the current Version 9.

2 In their main scenario, they assumed a free trade agreement and thus no tariffs between the UK and the EU27 following Brexit.

3 Jafari and Britz (2017) employed a Melitz-type CGE model, but did not compare its results with those of a conventional constant returns-to-scale (CRS) CGE model. PwC (2016) incorporated imperfect competition with product differentiation between heterogeneous firms, à la Dixit and Stiglitz (1977), in a single-country dynamic CGE model.
} 
trade barriers and reduce trade between the UK and the EU27, thereby deteriorating national welfare, and possibly accentuated by UK firm exit from EU27 export markets. Firm exit would then lower firm productivity and harm consumers through the loss of varieties supplied by the trade partners in the internal market.

In this paper, we develop two world trade CGE models. One is a standard constantreturns-to-scale (CRS) model. The other is an increasing-returns-to-scale (IRS) model, featuring the Melitz (2003) structure with firm heterogeneity. We conduct Brexit experiments using both these models, thereby capturing the effect of firm exit and the loss of variety induced by the restoration of trade barriers between the UK and the EU27. In particular, we examine: (1) the impact of new trade barriers between the UK and the EU27, (2) the effect of EU budget savings and the reduction in labor supply with the return of EU27 migrants, and (3) the influence of additional economic integration programs by the EU27 within the internal market and with the US and Japan. Using our numerical simulations with the IRS model, we predict a significant export loss of 5.1-5.8\% of UK GDP and a total welfare loss of $1-1.5 \%$, which is $60 \%$ larger than the welfare prediction of the CRS model. The impact of output should vary across industries. For example, while new trade barriers would protect the food industry in the UK, many other industries would contract, especially chemicals and automobiles. Likewise, the UK service sector would gain from a side effect of the trade barriers, but be harmed by the return of EU27 immigrant workers. In contrast, the EU27 would gain substantially from its other integration programs, but lose very little from the rise in the UK-EU27 border barriers.

The remainder of the paper is as follows. Section 2 describes our CGE models with/without IRS technology and firm heterogeneity. Section 3 presents our Brexit simulation scenarios and their backgrounds. The simulation results are in Section 4 , focusing on sectoral exports and value-added changes with household welfare impacts. Section 5 provides some concluding comments, followed by some qualifications, which suggest future research using a CGE model. The Appendix presents the sensitivity analysis of the 
simulation results in Section 4 along with details of the assumptions not presented in the main text.

\section{World Trade CGE Model with Melitz Structure}

Our world trade CGE models are static models with 12 regions, 21 sectors, and three primary factors (skilled and unskilled labor, and capital) (Tables 2.1-2.2). We assume the primary factors flexibly reallocate across sectors and equalize factor prices within each region. We develop two CGE model variants:

(1) Armington CGE model with CRS technology

(2) Melitz CGE model with IRS technology

In the IRS CGE model, we assume that seven manufacturing sectors are equipped with features, à la Melitz (2003) (Table 2.2) (hereafter the Melitz structure). Based on the CRS CGE model, which is a standard model used in many CGE analyses (Hosoe et al. 2010), we incorporate firm heterogeneity, product differentiation, and monopolistic competition following Dixon et al. (2016). Starting from the bottom of Figure 2.1, which describes the core part of the model structure, we assume that the domestic output of the $\dot{r}$ th sector in the $r$ th region $Z_{i, r}$ is produced using primary factors, intermediate input, and a fixed setup cost $H_{i, r}^{M L Z}$. Of $Z_{i, r}, Z Z_{k, i, r, s}$ is used to produce the $k^{\text {th }}$ variety shipped to the $s^{\text {th }}$ region (including that shipped to domestic region $r$ ) $Q T_{k, i, r, s}$ with a fixed variety production cost $F_{i, r, s}^{M L Z}$. The variety $Q T_{k, i, r, s}$ is aggregated into a variety composite good $Q T_{i, r, s}$ in the lower variety nest with a constant elasticity of substitution (CES) function and the elasticity of substitution $\sigma_{i}^{M L Z}$, à la Dixit and Stiglitz (1977). 
Table 2.1: Regional Aggregation

\begin{tabular}{lc}
\hline Regions & Abbreviation \\
\hline UK & GBR \\
EU 27 & EU27 \\
Benelux & BNL \\
France & FRA \\
Germany & DEU \\
Italy & ITA \\
Poland & POL \\
Spain & ESP \\
Sweden & SWE \\
Other EU & OEU \\
Japan & JPN \\
US & USA \\
Rest of the World (ROW) & ROW \\
\hline
\end{tabular}

Table 2.2: Sectors, Elasticity of Substitution $\sigma_{i}^{A R M}$, and UK Tariff Rate

\begin{tabular}{lcc}
\hline \multicolumn{1}{c}{ Sectors (abbreviation) } & $\begin{array}{c}\text { Elasticity of } \\
\text { substitution } \\
\sigma_{i}^{A R M} \text { b }\end{array}$ & $\begin{array}{c}\text { UK tariff rates applied } \\
\text { to non-EU members } \\
(\%) \mathrm{c}\end{array}$ \\
\hline Agriculture (AGR) & 2.39 & 2.6 \\
Mining (MIN) & 5.31 & 0.0 \\
Textiles and Apparel (TXA) & 3.78 & 7.2 \\
Food and Beverages (FOD) & 2.49 & 11.9 \\
Wood, Paper, and Printing (WPP) & 3.09 & 0.5 \\
Chemical (CHM) & 2.66 & 1.4 \\
Steel and Metal (STL) & 2.66 & 1.0 \\
Automotive (AUT)a & 2.66 & 4.3 \\
Other Transportation Equipment (OTE) a & 2.66 & 1.2 \\
Electric Equipment (EEQ) a & 2.66 & 1.1 \\
Machinery (MCH) a & 2.66 & 1.4 \\
Other Manufacturing (MAN) a & 2.66 & 1.0 \\
Air Transportation (ATR) & 1.90 & - \\
Water Transportation (WTR) & 1.90 & - \\
Other Transportation (OTR) & 1.90 & - \\
Business and ICT Service (ICT) & 1.90 & - \\
Finance and Insurance (FIN) & 1.90 & - \\
Communication (CMM) & 1.90 & - \\
Construction (CON) & 1.90 & - \\
Personal, Cultural, and Other Services (PCS) & 1.90 & - \\
Services (SRV) & 1.98 & - \\
\hline
\end{tabular}

a: IRS sectors equipped with the Melitz structure in the IRS CGE model.

$\mathrm{b}$ : The elasticity of 2.66 for the IRS sectors is assumed to be $70 \%$ of the lower "variety nest" elasticity $\sigma_{i}^{M L Z}(=3.8)$. For the remaining sectors, the elasticity is from the GTAP

Database Version 9A.

c: From the GTAP Database Version 9A. MFN tariff rates by the EU27 are similar to those of the UK, as reported in the Appendix. 
Figure 2.1: Core Structure of IRS CGE Model

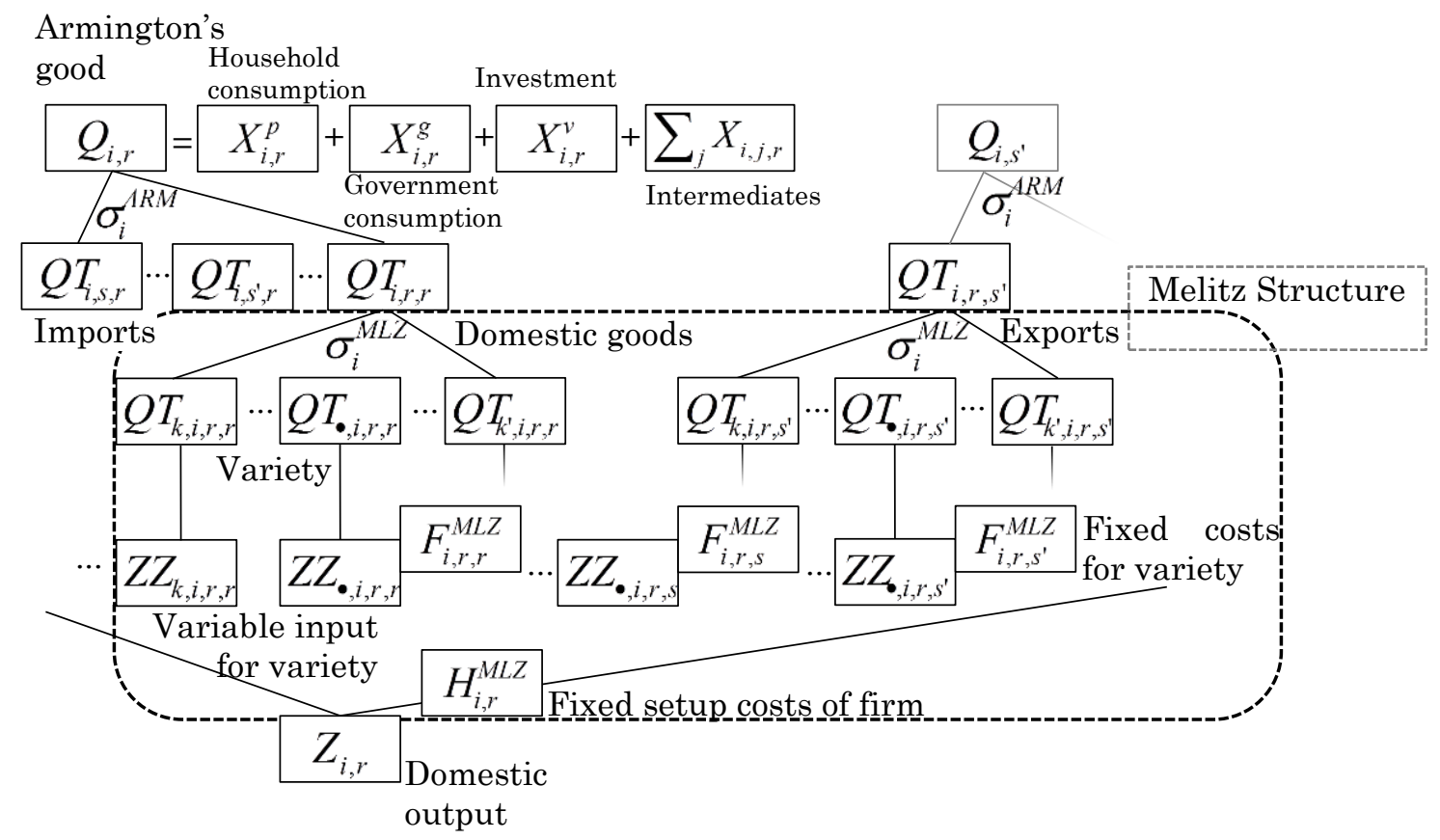

Note: This figure depicts the commodity flows of the $i$ th sector in the $r$ th region, as illustrated for a single-country model by Hosoe et al. (2010). The production process of the domestic output $Z_{i, r}$ omitted for simplicity. Trade partners are denoted $r, s$, and $s^{\prime}$; variety producers denoted $k$ and $k$. The dot • represents the "average productivity firm."

The fixed costs $H_{i, r}^{M L Z}$ and $F_{i, r, s}^{M L Z}$ are measured in terms of domestic output $Z_{i, r}$ units, following Itakura and Oyamada (2015). Incidentally, while Melitz (2003) originally measured these fixed costs in terms of labor units, there have been alternative approaches in its CGE implementation. For example, Zhai (2008) assumed a combination of capital, labor, and intermediates for the fixed inputs, while Balistreri and Rutherford (2013) used a composite factor (i.e., a mix of capital and labor). A draw from a Pareto distribution determines a firm's productivity. In this setup, while all the operating firms ship their output to the domestic market, only very productive firms that can afford the fixed cost of export. ${ }^{4}$

The Armington (1969) composite good $Q_{i, r}$ is produced using the variety composite

\footnotetext{
4 The model equation list is in the Annex, available upon request.
} 
$Q T_{i, s, r}$ supplied from all regions according to a CES aggregation function with an elasticity of substitution of $\sigma_{i}^{A R M}$. When we use the same elasticity value for $\sigma_{i}^{A R M}$ and $\sigma_{i}^{M L Z}$, the two-stage nested CES functions reduce to a single stage, as originally employed by Melitz (2003). Departing from Melitz's original model, we distinguish between these elasticities so that we can separately examine the effect of the heterogeneity among goods across source regions (the Armington structure) and the effect of firm heterogeneity and product differentiation (the Melitz structure) on productivity in the seven IRS sectors. The former mainly describes the trade reaction; the latter the intensity of the scale economies and monopolistic power. While maintaining country tastes, this extension can facilitate consideration of different markups (or competition intensity) between markets (De Loecker et al. (2016)).

The two-nest modeling approach provides another benefit. When we assume a smaller value for $\sigma_{i}^{A R M}$ in the upper nest than that for $\sigma_{i}^{M L Z}$ in the lower nest, equilibrium computation becomes quite smooth and robust, whereas existing studies using Melitz-type CGE models often face a computational difficulty because of its extreme nonconvexity. For example, Balistreri and Rutherford (2013) developed an algorithm that iteratively solves a CRS CGE model with exogenous productivity and a Melitz-type partial equilibrium model to estimate productivity changes induced by trade volume changes estimated by the CRS CGE model. Akgul et al. (2010) linearized the model system. Other studies compromised with a simpler CGE model featuring a small number of IRS sectors and/or a smaller number of sectors and regions to manage the computational problem.

The CRS CGE model (as well as the CRS sectors in the IRS CGE model) is not equipped with this Melitz structure. The domestic output $Z_{i, r}$ serves directly in the production of $Q T_{i, r, s}$ without any variety or fixed costs. Many CGE models are equipped with a constant elasticity of transformation (CET) function to determine the allocation between exports and domestic supply (i.e., imperfect transformation). However, like other Melitz-type 
CGE models, our IRS and CRS models do not include any CET function (or equivalently, they assume the perfect transformation between exports and domestic supply) in order to make the model structures of our CRS and IRS models similar and to highlight the role of the Melitz structure.

The Armington composite good $Q_{i, r}$ is used by domestic agents, comprising households $X_{i, r}^{p}$, governments $X_{i, r}^{g}$, investment $X_{i, r}^{v}$, and intermediates $X_{i, j, r}$. The utility of a representative household depends on household consumption and a CobbDouglas-type utility function. We assume governments keep their consumption level $X_{i}^{g}$ constant, irrespective of revenues from indirect taxes and import tariffs, with fiscal gaps filled by a lump-sum direct tax on households. This approach results in any EU budget savings as being eventual transfers from EU27 to UK households, not between their respective governments. Therefore, we do not need any assumption about government expenses concerning the budget savings.

Investment use $X_{i}^{v}$ is also constant. We include two foreign exchange regimes in the model: a pegged exchange rate system between the Eurocurrency regions (Benelux, France, Germany, Italy, Spain, and the other EU) and a floating system for all others. ${ }^{5}$ We allow foreign savings to change endogenously among the former and fix foreign savings in the ROW's currency term for the latter. ${ }^{6}$ Lump-sum household savings fill any investmentsavings gaps to ensure constant investment.

We calibrate the model to the GTAP Database Version 9A, which has a reference

\footnotetext{
5 For simplicity, we assume the non-Euro countries in the 'Other EU' region (Bulgaria, Croatia, Czech, Denmark, Hungary, and Romania) are in the Euro region.

${ }^{6}$ As foreign savings are equivalent to transfers in this static model context (Hosoe et al. 2010, Ch. 7), reporting outcomes for the individual regions in the Eurocurrency countries could be very misleading. Therefore, we only report the aggregate results for the entire EU27, not for its individual regions.
} 
year of 2011 (Hertel 1997). For the parameters that characterize the Melitz structure, we use the estimate of 3.8 by Bernard et al. (2003) for $\sigma_{i}^{M L Z}$ and the estimate of 4.6 by Balistreri et al. (2011) for the shape parameter of the Pareto distribution $\alpha_{i}^{M L Z}$, which determines the degree of firm heterogeneity. As comparable parameter estimates are uncommon, we apply the same parameter values for all seven IRS sectors in all regions, following standard practice in CGE analysis, such as Dixon et al. (2016) and Balistreri and Rutherford (2013). The elasticity of substitution $\sigma_{i}^{A R M}$ in the Armington (1969) nest is from the GTAP Database for the 14 sectors, assumed CRS sectors in the IRS model (Table 2.2). We assume 2.66 for $\sigma_{i}^{A R M}$ in the other seven sectors, assumed IRS sectors in the IRS model. This assumption is based on a $30 \%$ smaller value of the lower nest elasticity of substitution between varieties $\sigma_{i}^{M L Z}{ }^{7}$

\section{Simulation Scenarios}

While Brexit should result in a variety of changes in European economic and political systems, we focus on the essential factors likely realized in the near future that would affect UK-EU27 trade. This trade is particularly important for the UK because the EU27 represents about half of UK exports, but the UK only 10\% of EU27 exports. We consider the following seven scenario factors, which comprise the total Brexit shock (ALL) (Table 3.1). Details are below.

7 To check the robustness of our simulation results with respect to this assumption, we conduct sensitivity analysis as shown in the Appendix. 
Table 3.1: Main Simulation Scenarios

\begin{tabular}{lc}
\hline Scenarios & Abbreviation \\
\hline Brexit with all the scenario factors & ALL \\
of which & \\
Direct/Short-run Impact & \\
(1) EU Budget Savings & BUD \\
(2) UK-EU MFN Tariff Imposition & TRF \\
(3) UK-EU NTB Rise & NTB-UK \\
(4) Returning Migrants from the UK & MIG \\
Indirect/Long-run Impact & \\
(5) Deeper EU27 Integration through NTB Reduction & \\
(6) FTA with Japan & NTB-EU \\
(7) FTA with the US & FTA-JP \\
\hline
\end{tabular}

a: Scenarios that have lower and upper sub-scenarios about the magnitude of the NTB changes.

\subsection{EU Budget Contribution Saving (BUD)}

By leaving the EU, the UK no longer has to contribute to the EU budget. In 20112013, this amounted to $0.5 \%$ of UK GDP (HM Treasury 2013). We follow Dhingra et al. (2017) and use their conservative estimate, as great as $0.3 \%$ of UK GDP, for the expected savings. Similarly, Núñez Ferrer and Rinaldi (2016) estimated that the budget savings would be about 0.4\% of UK GDP for 2014. We model these savings as transfers from the EU27 regions back to the UK, with the cost of transfers (in GBP), borne and allocated among the eight EU27 regions in proportion to their present GDP. As Núñez Ferrer and Rinaldi (2016) suggested that the gross budget contribution changes involved with Brexit among the EU27 would not be sizable, our assumption concerning the allocation of the additional budget burden among the EU27 regions is not critical. In turn, UK households directly capture these budget saving benefits. As explained in Section 2, the UK government does not use the budget savings for its own operations or any other programs (e.g., National Health Service) in our simulation experiments.

\subsection{Tariff Imposition between the UK and the EU27 (TRF)}

Both regions are assumed to impose import tariffs as high as those that they 
presently apply to non-EU members. Many Brexit studies refer to this as the World Trade Organization (WTO) option, which follows the MFN principle. Table 2.2 shows that as often observed in many developed countries, MFN tariff rates are very low. TXA and FOD are exceptions as major goods in household consumption. Therefore, we expect the MFN tariff imposition between the UK and the EU27 to affect household welfare substantially. Alternatively, we could assume that following (successful) Brexit negotiations, the UK and the EU27 would reach a free trade agreement (FTA), similar to that the EU already has with Norway and Switzerland. Although we consider only the WTO option in our experiments, we could easily infer the outcome of the FTA option from a breakdown of the simulation results in Section 4.

\subsection{NTB Rise between UK and EU27 (NTB-UK)}

NTBs will increase with Brexit, but the result is difficult to observe directly. As there is no direct estimate of the (ad valorem tariff-equivalent rate) NTBs newly set between the UK and the EU27, we use Ecorys' (2009) estimate of existing NTBs by the EU for the US (Table 3.2). ${ }^{8}$ Ecorys (2009) argues that only part of the NTBs would be 'actionable' or reducible even in a full-liberalization case because some of the barriers-for example, language barriers, and sanitary and phytosanitary regulations-could not be removed. The actionable NTBs are broken into two components: cost creating and rent creating. ${ }^{9}$ Following the conservative assumption by Dhingra et al. (2017), we assume that only a quarter of the EU NTB estimates currently set against US exports will be newly set between the UK and

\footnotetext{
8 Egger et al. (2016) provides alternative estimates of intra-EU NTBs on goods larger than Ecorys' (2009) estimates we employ.

9 The median of Ecorys' (2009) estimates that are summarized in the Appendix indicate that the actionable part comprises about a half of the total NTB and that the cost-creating NTB accounts for about $60 \%$ of the actionable NTBs.
} 
the EU27. Given the significant uncertainty regarding the new UK-EU27 NTBs, we prepare two sub-scenarios for the NTB changes following Ecorys (2009). The lower NTB sub-scenario employs the NTB estimates based only on the cost-creating part; the upper NTB sub-scenario uses a more aggressive assumption with the NTB estimates of the whole actionable part (i.e., both cost and rent creating) (Table 3.3). We incorporate NTBs as iceberg-type transportation costs in our model. We present and discuss the simulation results given the lower NTB subscenario in the main text and the results with the upper NTB sub-scenario in the Appendix.

Table 3.2: Assumed Bilateral Ad Valorem Tariff Equivalent NTBs [\%]

\begin{tabular}{|c|c|c|c|c|c|c|c|c|c|c|c|c|c|}
\hline $\begin{array}{l}\text { From: } \\
\text { To: }\end{array}$ & $\begin{array}{c}\text { EU } \\
\text { BNL }\end{array}$ & $\begin{array}{c}\mathrm{EU} \\
\mathrm{OEU}\end{array}$ & $\begin{array}{c}\text { EU } \\
\text { FRA }\end{array}$ & $\begin{array}{l}\text { EU } \\
\text { DEU }\end{array}$ & $\begin{array}{l}\text { EU } \\
\text { ITA }\end{array}$ & $\begin{array}{l}\mathrm{EU} \\
\mathrm{POL}\end{array}$ & $\begin{array}{l}\text { EU } \\
\text { ESP }\end{array}$ & $\begin{array}{c}\text { EU } \\
\text { SWE }\end{array}$ & $\begin{array}{l}\text { EU27/GBR } \\
\text { GBR/EU27 }\end{array}$ & $\begin{array}{l}\text { EU } \\
\text { JPN }\end{array}$ & $\begin{array}{c}\text { EU } \\
\text { USA }\end{array}$ & $\begin{array}{c}\text { JPN } \\
\text { EU }\end{array}$ & $\begin{array}{l}\text { USA } \\
\text { EU }\end{array}$ \\
\hline AGR & 27.6 & 31.0 & 30.3 & 33.7 & 34.0 & 33.5 & 32.4 & 32.0 & 32.2 & & & & \\
\hline TXA & 39.9 & 45.7 & 44.6 & 44.0 & 45.0 & 45.9 & 46.3 & 44.7 & 46.3 & & 16.7 & & 19.2 \\
\hline FOD & 48.4 & 63.6 & 63.8 & 63.7 & 65.0 & 63.8 & 64.7 & 62.4 & 64.2 & 25.0 & 73.3 & & 56.8 \\
\hline WPP & 1.9 & 5.5 & 3.0 & 8.4 & 5.4 & 5.5 & 8.3 & 9.3 & 14.7 & 15.4 & 7.7 & & 11.3 \\
\hline CHM & 32.2 & 44.4 & 40.5 & 43.5 & 42.8 & 45.6 & 44.1 & 42.1 & 44.8 & 22.0 & 21.0 & 18.0 & 23.9 \\
\hline STL & 1.7 & 4.3 & 1.9 & 5.1 & 4.6 & 5.5 & 4.7 & 6.3 & 4.9 & 21.3 & 17.0 & 6.0 & 11.9 \\
\hline AUT & 1.5 & 2.5 & 2.2 & 3.7 & 3.1 & 2.0 & 2.1 & 3.4 & 2.4 & 10.0 & 26.8 & 16.3 & 25.5 \\
\hline OTE & 3.3 & 13.4 & 2.3 & 3.6 & 5.4 & 2.6 & 6.5 & 9.0 & 2.5 & 45.0 & 19.1 & 18.8 & 18.8 \\
\hline EEQ & 3.9 & 5.4 & 5.6 & 8.8 & 9.2 & 4.6 & 10.5 & 13.8 & 8.7 & 11.6 & 6.5 & 4.5 & 6.5 \\
\hline $\mathrm{MCH}$ & 4.2 & 6.1 & 4.8 & 9.6 & 7.5 & 5.3 & 7.9 & 10.3 & 7.9 & 30.0 & & & \\
\hline MAN & 40.1 & 55.5 & 58.2 & 55.4 & 57.0 & 54.9 & 56.6 & 50.6 & 54.0 & & & & \\
\hline ATR & 13.6 & 13.3 & 14.2 & 17.7 & 15.6 & 13.6 & 11.5 & 16.4 & 18.9 & 2.0 & & 2.0 & \\
\hline WTR & 37.2 & 35.2 & 38.7 & 38.8 & 41.7 & 37.9 & 34.4 & 40.6 & 39.9 & 8.0 & & 8.0 & \\
\hline OTR & 13.6 & 13.3 & 14.2 & 17.7 & 15.6 & 13.6 & 11.5 & 16.4 & 18.9 & & & & \\
\hline ICT & 20.7 & 20.0 & 19.1 & 24.9 & 24.0 & 21.4 & 21.8 & 23.7 & 20.2 & 2.5 & 3.9 & 14.9 & 14.9 \\
\hline FIN & 25.5 & 24.7 & 20.4 & 25.4 & 24.8 & 24.5 & 24.4 & 25.5 & 29.4 & 15.8 & 31.7 & 11.3 & 11.3 \\
\hline INS & 42.4 & 42.2 & 38.6 & 42.8 & 43.8 & 42.2 & 42.6 & 42.9 & 44.0 & 6.5 & 19.1 & 10.8 & 10.8 \\
\hline CMM & 20.9 & 20.9 & 18.8 & 23.0 & 23.5 & 21.0 & 21.5 & 24.8 & 22.6 & 24.7 & 1.7 & 11.7 & 11.7 \\
\hline $\mathrm{CON}$ & 24.9 & 24.6 & 20.4 & 35.3 & 27.3 & 27.5 & 26.0 & 31.0 & 27.6 & 2.5 & 2.5 & 4.6 & 4.6 \\
\hline PCS & 25.0 & 24.8 & 23.9 & 28.5 & 27.2 & 25.1 & 23.6 & 27.3 & 30.1 & 6.5 & 2.5 & 4.4 & 4.4 \\
\hline SRV & 25.0 & 24.8 & 23.9 & 28.5 & 27.2 & 25.1 & 23.6 & 27.3 & 30.1 & & & & \\
\hline
\end{tabular}

Sources: Ecorys (2009) for the US-EU, Copenhagen Economics (2010) for Japan, Aussilloux et al. (2011) for intra-EU, and author's own assumptions.

Note: NTBs between the UK and the EU27 are presently zero but increase in the NTB-UK scenario. 
Table 3.3: Assumed Change in NTBs in a Lower NTB Sub-scenario [\% points]

\begin{tabular}{|c|c|c|c|c|c|c|c|c|c|c|c|c|c|}
\hline $\begin{array}{l}\text { From: } \\
\text { To: }\end{array}$ & $\begin{array}{r}\mathrm{EU} \\
\mathrm{BNL}\end{array}$ & $\begin{array}{l}\text { EU } \\
\text { OEU }\end{array}$ & $\begin{array}{l}\text { EU } \\
\text { FRA }\end{array}$ & $\begin{array}{c}\text { EU } \\
\text { DEU }\end{array}$ & $\begin{array}{l}\text { EU } \\
\text { ITA }\end{array}$ & $\begin{array}{c}\text { EU } \\
\text { POL } \\
\end{array}$ & $\begin{array}{l}\text { EU } \\
\text { ESP }\end{array}$ & $\begin{array}{c}\text { EU } \\
\text { SWE }\end{array}$ & $\begin{array}{l}\text { EU27/GBR } \\
\text { GBR/EU27 }\end{array}$ & $\begin{array}{l}\text { EU27 } \\
\text { JPN }\end{array}$ & $\begin{array}{c}\text { EU27 } \\
\text { USA }\end{array}$ & $\begin{array}{c}\text { JPN } \\
\text { EU27 }\end{array}$ & $\begin{array}{c}\text { USA } \\
\text { EU27 }\end{array}$ \\
\hline AGR & -8.3 & -9.3 & -9.1 & -10.1 & -10.2 & -10.1 & -9.7 & -9.6 & & & & & \\
\hline TXA & -12.0 & -13.7 & -13.4 & -13.2 & -13.5 & -13.8 & -13.9 & -13.4 & 1.6 & & -6.9 & & -6.5 \\
\hline FOD & -14.5 & -19.1 & -19.1 & -19.1 & -19.5 & -19.1 & -19.4 & -18.7 & 5.2 & -6.0 & -23.9 & & -20.8 \\
\hline WPP & -0.6 & -1.7 & -0.9 & -2.5 & -1.6 & -1.7 & -2.5 & -2.8 & 1.2 & -7.1 & -3.6 & & -4.7 \\
\hline CHM & -9.6 & -13.3 & -12.1 & -13.1 & -12.8 & -13.7 & -13.2 & -12.6 & 2.3 & -15.0 & -8.0 & -7.3 & -9.2 \\
\hline STL & -0.5 & -1.3 & -0.6 & -1.5 & -1.4 & -1.7 & -1.4 & -1.9 & 0.7 & -4.3 & -5.6 & -1.9 & -2.7 \\
\hline AUT & -0.5 & -0.8 & -0.7 & -1.1 & -0.9 & -0.6 & -0.6 & -1.0 & 2.1 & -1.2 & -7.3 & -3.5 & -8.2 \\
\hline OTE & -1.0 & -4.0 & -0.7 & -1.1 & -1.6 & -0.8 & -2.0 & -2.7 & 1.6 & -33.8 & -5.3 & -3.1 & -6.2 \\
\hline EEQ & -1.2 & -1.6 & -1.7 & -2.6 & -2.8 & -1.4 & -3.2 & -4.1 & 0.4 & -2.6 & -1.6 & -1.7 & -1.7 \\
\hline $\mathrm{MCH}$ & -1.3 & -1.8 & -1.4 & -2.9 & -2.3 & -1.6 & -2.4 & -3.1 & & -2.9 & & & \\
\hline MAN & -12.0 & -16.7 & -17.5 & -16.6 & -17.1 & -16.5 & -17.0 & -15.2 & & & & & \\
\hline ATR & -4.1 & -4.0 & -4.3 & -5.3 & -4.7 & -4.1 & -3.5 & -4.9 & & -0.9 & & -0.4 & \\
\hline WTR & -11.2 & -10.6 & -11.6 & -11.6 & -12.5 & -11.4 & -10.3 & -12.2 & & -3.5 & & -1.4 & \\
\hline OTR & -4.1 & -4.0 & -4.3 & -5.3 & -4.7 & -4.1 & -3.5 & -4.9 & & & & & \\
\hline ICT & -6.2 & -6.0 & -5.7 & -7.5 & -7.2 & -6.4 & -6.5 & -7.1 & 0.7 & -2.5 & -1.4 & -2.5 & -2.9 \\
\hline FIN & -7.7 & -7.4 & -6.1 & -7.6 & -7.4 & -7.4 & -7.3 & -7.7 & 0.6 & -5.8 & -9.8 & -2.9 & -2.3 \\
\hline INS & -12.7 & -12.7 & -11.6 & -12.8 & -13.1 & -12.7 & -12.8 & -12.9 & 0.7 & -0.8 & -5.5 & -2.8 & -2.8 \\
\hline CMM & -6.3 & -6.3 & -5.6 & -6.9 & -7.1 & -6.3 & -6.5 & -7.4 & 1.1 & -12.8 & -0.5 & -4.3 & -4.3 \\
\hline CON & -7.5 & -7.4 & -6.1 & -10.6 & -8.2 & -8.3 & -7.8 & -9.3 & 0.3 & -1.2 & -0.8 & -1.9 & -1.3 \\
\hline PCS & -7.5 & -7.4 & -7.2 & -8.6 & -8.1 & -7.5 & -7.1 & -8.2 & 0.2 & -2.5 & -0.3 & -1.0 & -0.6 \\
\hline SRV & -7.5 & -7.4 & -7.2 & -8.6 & -8.1 & -7.5 & -7.1 & -8.2 & & & & & \\
\hline
\end{tabular}

Sources: Ecorys (2009), Copenhagen Economics (2010), Aussilloux et al. (2011), and author's own assumptions.

Note: The upper sub-scenario assumptions are in the Appendix.

\subsection{Returning Migrants from UK (MIG)}

Brexit will no longer permit the free movement of workers from outside the UK, with more rigorous immigration procedures and regulations applied to foreign labor. As the UK currently accepts more immigrants from the EU27 than emigrants to the EU27, the UK will lose its (immigrant) labor supply following Brexit. The GMig2 Database, which is a satellite database of the GTAP Database (Walmsley et al. 2005), reports that wages amounting to $1.2 \%$ of UK GDP are currently paid to EU27 nationals in the UK and $0.57 \%$ of UK GDP (or 0.09\% of EU27 GDP) is paid to the UK nationals in the EU27. That is, the UK pays net wages to nationals from the EU27 equal to $0.63 \%$ of UK GDP (or $0.10 \%$ of EU27 GDP).

While there is much uncertainty about the new immigration policy, we assume $50 \%$ of net immigrants will leave the UK, with the returning migrants allocated among the eight EU27 regions according to their regional GDP. In our experiments, we model this a shift in skilled and unskilled labor endowment from the UK to the EU27. More specifically, we assume the UK will lose $0.52 \%$ and $0.83 \%$ of its total skilled and unskilled labor endowment, respectively. In comparison, Kirkegaard (2017) estimated that the growth rate of the UK 
labor force of about $0.4 \%$ p.a. in 2016 would fall to almost zero if the Conservative Party's immigration policy of limiting the annual flow of new immigrants to 100,000 persons came into effect. By contrast, the more aggressive immigration policy assumed by PwC (2016) implies that UK employment would fall by $1.7-2.9 \%$ in the short run.

\subsection{Further Integration of EU27 through NTB Reduction (NTB-EU)}

Brexit will leave the UK behind further and faster integration within the EU27. This will likely divert EU27 export destinations and import sources from the UK to intraEU27 and more severely harm the post-Brexit UK economy. As the internal market no longer has import tariffs to reduce among its members, only intra-EU27 NTBs will fall. Aussilloux et al. (2011) provide the intra-EU NTB estimates, and Egger et al. (2015) also estimated intra-EU NTBs, which are generally consistent with those in Aussilloux et al. (2011). As these did do not separately report the actionable (or cost-creating) parts, using the median estimates in Ecorys (2009) of EU NTBs for US exports, we employ a ballpark assumption that $50 \%$ of the reported NTBs are actionable and that $60 \%$ of the actionable NTBs are attributable to cost-creating NTBs.

\subsection{FTAs with US and Japan (FTA-US and FTA-JP)}

The EU has carried out FTA negotiations with major economies outside the internal market. One is with the US, known as the Transatlantic Trade and Investment Partnership (TTIP), whose impact has been assessed by, for example, Ecorys (2009), Egger et al. (2015), and Latorre and Yonezawa (2017). Another is an FTA with Japan, as assessed by Copenhagen Economics (2010), European Commission (2016), and others. We consider tariff abolition between the EU27 and the US or Japan along with their reciprocal NTB reductions. We rely on Ecorys (2009) and Copenhagen Economics (2010) for estimates of the ad-valorem tariff equivalent NTBs and their actionable and cost-creating components to prepare the 
lower and upper sub-scenarios for NTB reduction, as with the UK-EU27 NTB estimates and changes (Tables 3.2-3.3). Our objective is to measure the UK loss in trade and welfare from trade diversion by the EU27.

\section{Simulation Results}

\subsection{Shrinking UK-EU27 Trade}

Brexit would substantially reduce bilateral exports between the UK and the EU27 through both higher mutual trade barriers and by trade diversion induced by deeper integration within the EU27, and with the US and Japan (Figure 4.1). Manufacturing exports would particularly suffer. From the base, TXA and FOD would reduce their UK exports around $40 \%$ and the EU27 exports around 30\%. These reductions are attributable not only to their relatively high MFN tariffs (Table 2.2) but also to the NTB rise (Table 3.3). CHM would also experience a comparable decline in the UK exports, despite the imposition of a small tariff (1.4\%) and an NTB rise (2.3\%). Being subject to the third-highest MFN tariff barrier of $4.3 \%$ in the UK plus a tariff-equivalent NTB rise of $2.1 \%$, AUT would suffer a loss of around $20 \%$ of export. In contrast, facing smaller NTB rises and no tariff rise, UK service exports would increase moderately, except for the transportation sector. 
Figure 4.1: Total Impact of Brexit (ALL) on UK-EU27 Bilateral Exports

[Change from Base, \%]

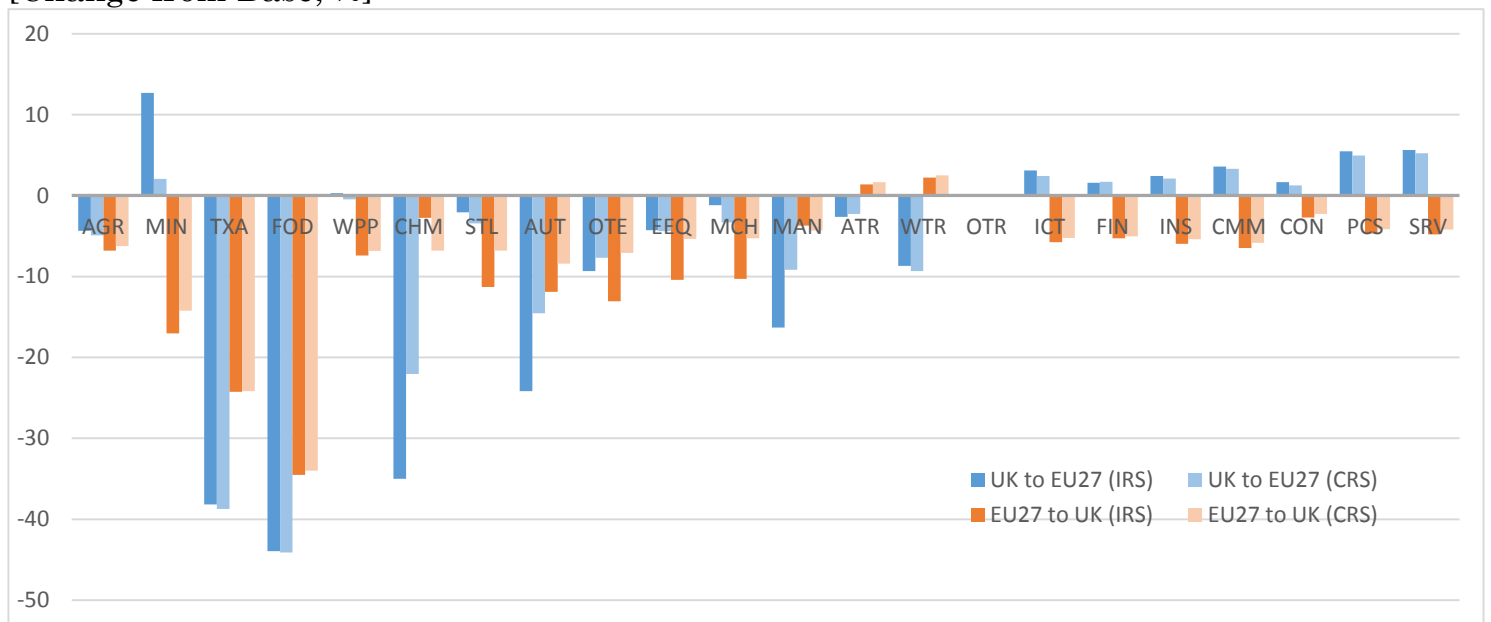

[Export Value Change, \% of UK GDP]

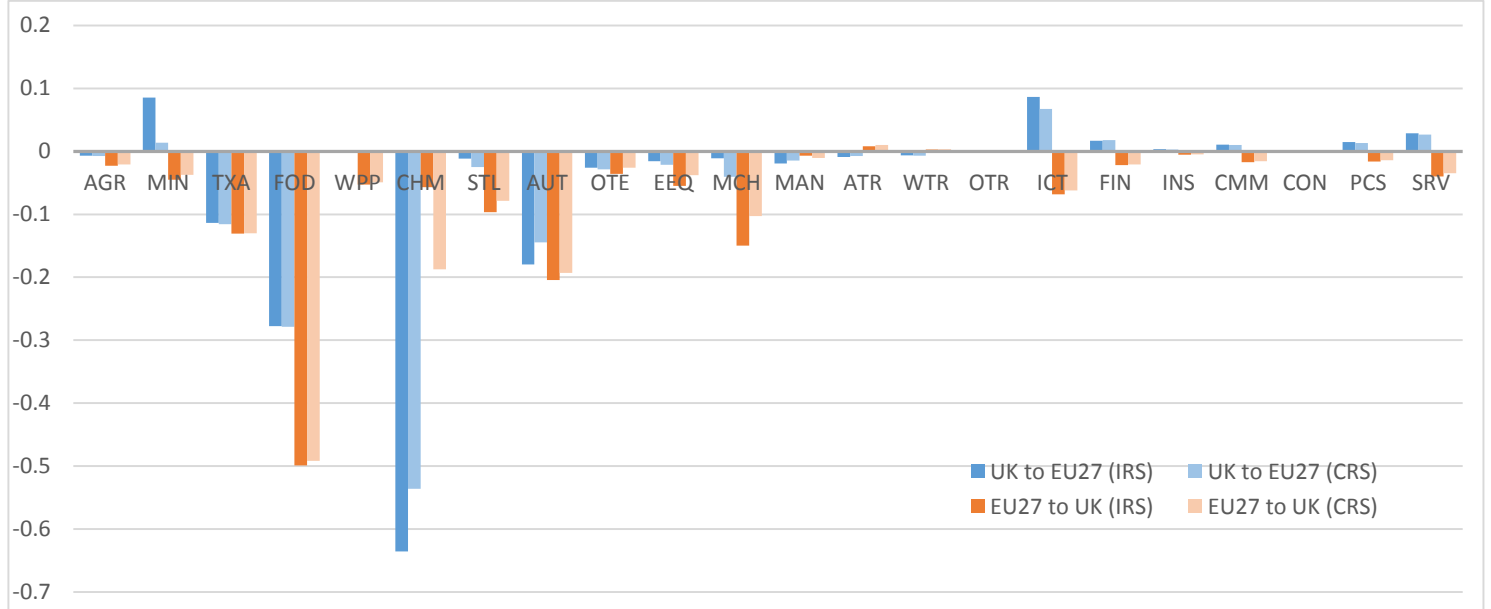

Note: IRS and CRS are the results of the IRS and CRS models, respectively. Results of the upper NTB sub-scenario are in the Appendix.

As the theory of firm heterogeneity suggests (e.g., Arkolakis et al. 2012), the IRS CGE model predicts larger impacts. For example, the IRS model predicts a $24 \%$ larger AUT export loss than the CRS model. This large trade loss, induced by the very moderate tariff (4.3\%) and NTB (2.1\% of an ad valorem tariff equivalent barrier) increases, is exacerbated by the decrease in their extensive margins, which the Melitz IRS model can describe with firm exit (Figure 4.2). This suggests a drastic contraction of this industry in the UK, which is an export platform for automotive products into the internal market (Inagaki 2016). The number of UK AUT export varieties to the EU27 would also fall by $20 \%$ and the industry would become more oriented to the domestic market. 
Figure 4.2: Impact of Brexit (ALL) on Number of Firms by Supply Destination in the UK (top) and EU27 (bottom)

[\% Change from Base]

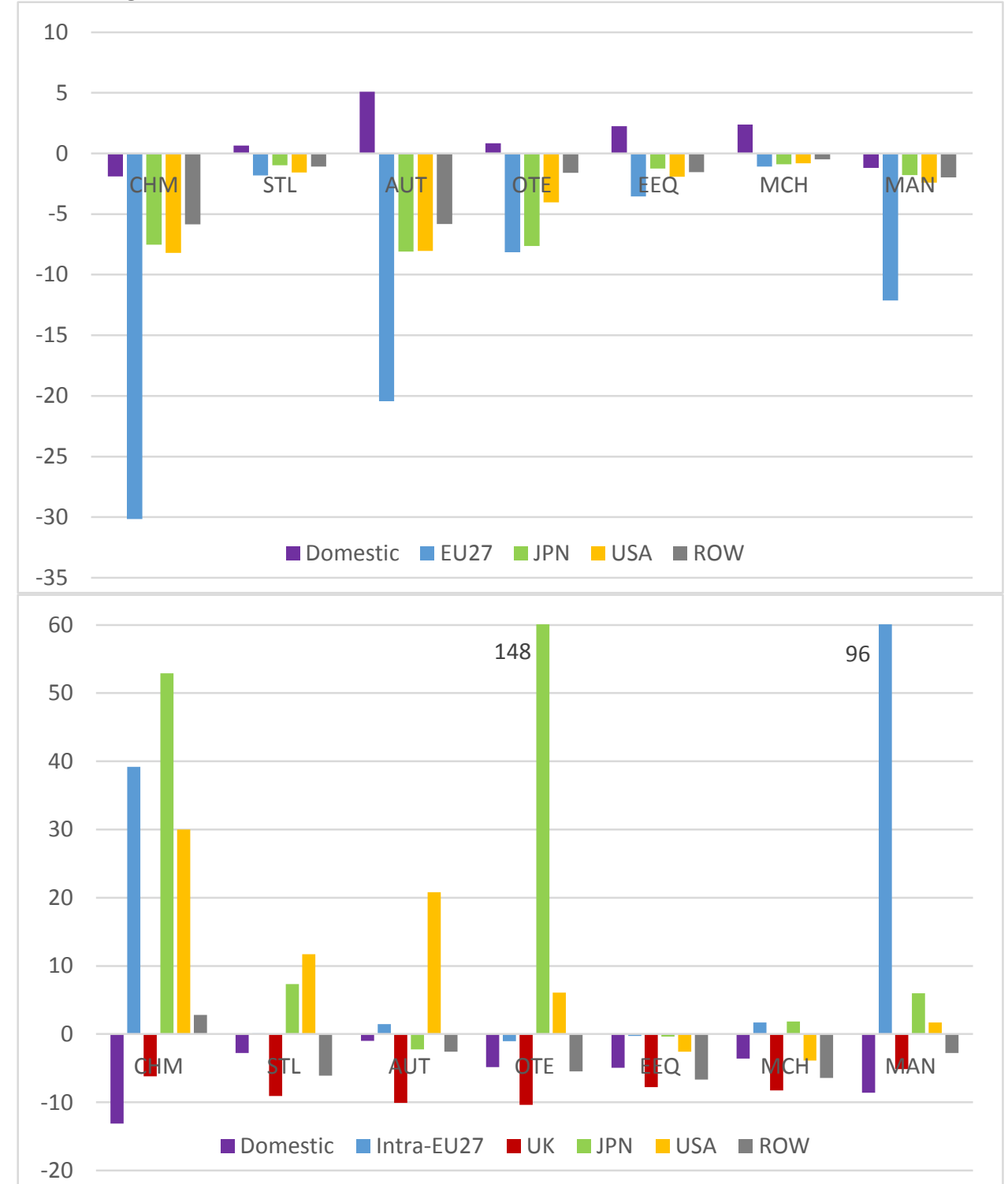

Note: Results with the upper NTB sub-scenario in the Appendix.

EU27 exports to the UK (or UK imports from the EU27) would also experience a fall, mainly in terms of goods. These are sometimes more substantial than the UK export losses. The manufacturing export volume losses range from $10 \%$ to $30 \%$ from the base (top panel of Figure 4.1), which are exacerbated by losses of export varieties to the UK of nearly 10\% (bottom panel of Figure 4.2). The EU27 would also reduce their service exports to the 
UK, especially in ICT and SRV. However, these goods and services export losses do not imply that EU27 total exports (to both the UK and other regions) would suffer more seriously than UK total exports (Figure 4.3). EU27 aggregate exports to the UK would fall not only by the UK-EU27 trade barriers but also by trade diversion induced by greater integration with other regions. In contrast to the sharp fall in UK exports, the EU27 export loss to the UK would be only a small fraction of the changes in trade volume. Deeper intra-EU27 integration and FTAs with the US and Japan would provide the EU27 with better export opportunities, especially in TXA, FOD and CHM along with AUT. Incidentally, CHM and AUT in the UK would also lose access to the US market owing to trade diversion under the TTIP, although the FTA with Japan would not have any visible trade diversion effect on UK exports. 
Figure 4.3: Impact of Brexit (ALL) on Exports for the UK (top) and EU27 (bottom) by Direction Predicted with an IRS Model

[Export Value Change, \% of UK and EU27 GDP]

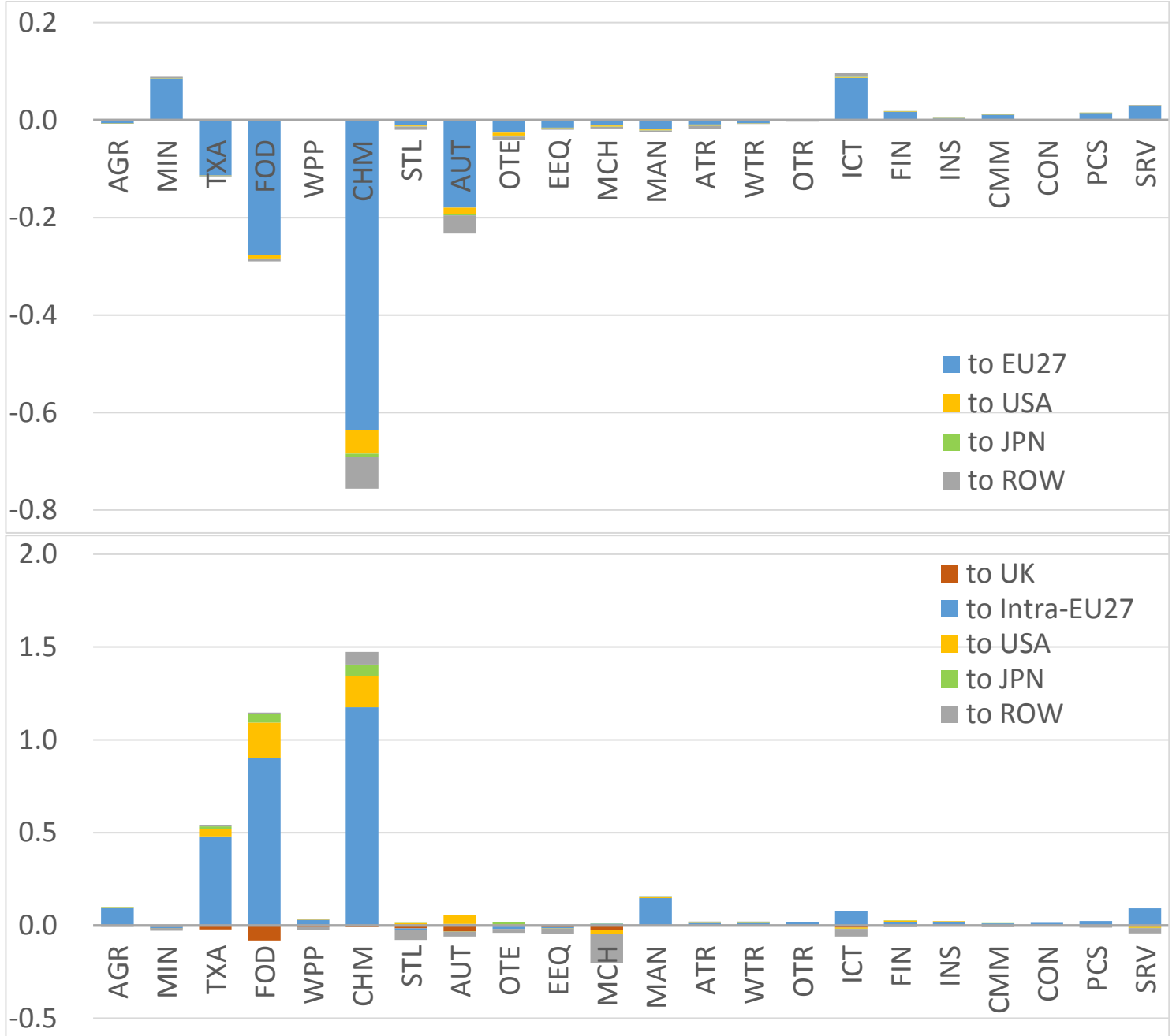

Note: Results with the CRS Model and/or with upper NTB sub-scenario in the Appendix.

The aggregate export volume change confirms the above findings (Figure 4.4). The UK would lose exports as great as 5\% of its GDP, mostly through the UK-EU27 border tariff (TRF) and NTB rise (NTB-UK). The EU budget saving (BUD) becomes the third-largest negative factor for the export contraction, at the same time as being an expected pecuniary benefit for the UK. This is because the budget saving, being an eventual transfer from the EU27 makes the Euro relatively abundant, and thus it depreciates against the GBP, thereby reducing UK exports. The EU27 would increase exports through further intra-EU27 integration (NTB-EU) and by the TTIP (FTA-US). In contrast, TRF and NTB-UK would 
only marginally reduce EU27 exports, while export losses by the UK and gains by the EU27 would intensify when we use the IRS model, which tends to predict a larger trade reaction to the border barrier changes.

Figure 4.4: Aggregate Export Changes by Scenario Factor with the Lower NTB Sub-scenario [Export Value Change, \% of UK and EU27 GDP]

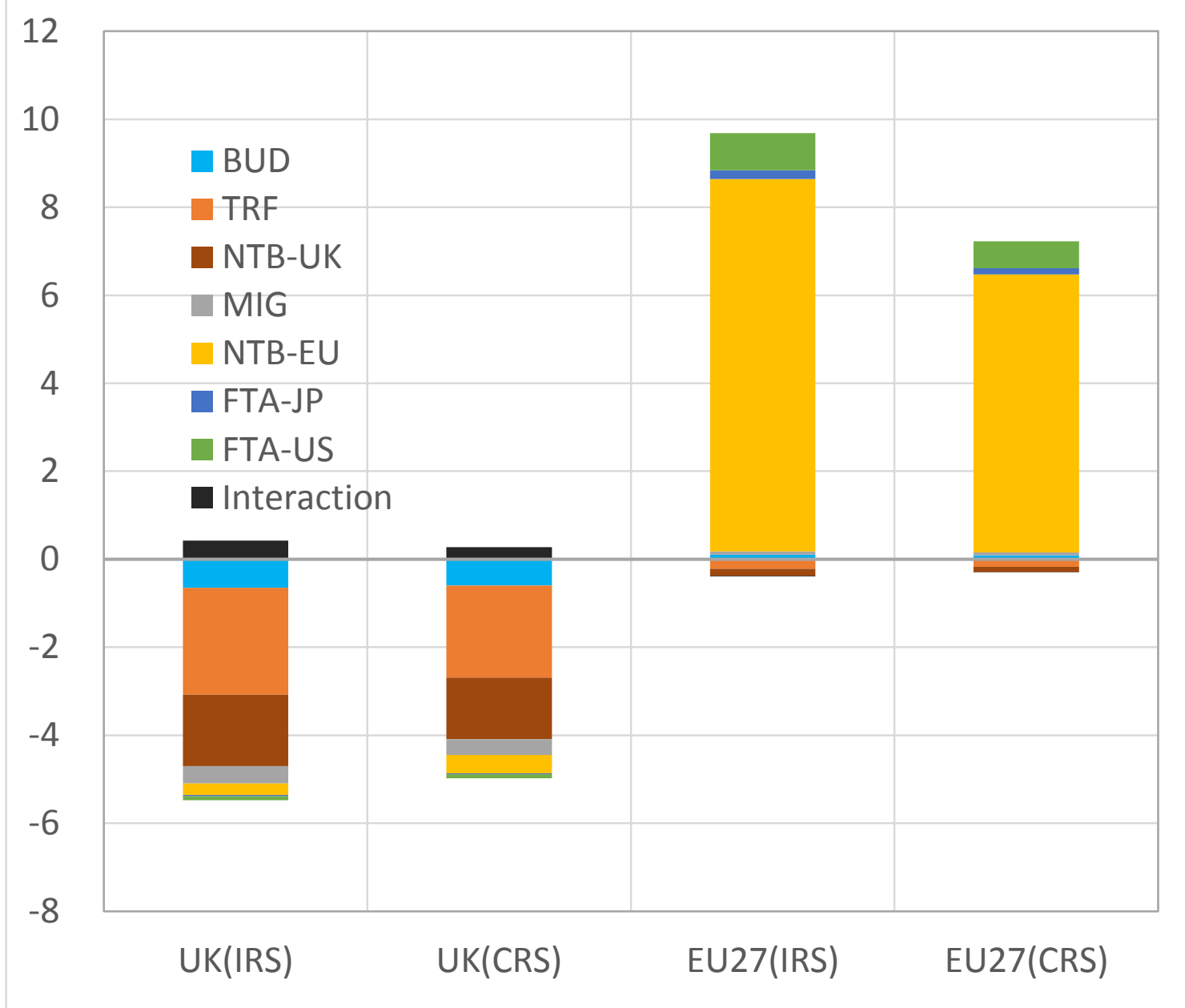

Note: Results with the upper NTB sub-scenario are in the Appendix.

\subsection{Costs and Benefits of Protectionism}

Brexit (ALL) could protect some particular sectors (FOD, WPP, MCH, and ICT) in the UK. However, as predicted by the IRS model, this would only be to a very small extent 
(Figure 4.5).10 In addition, this protection is only possible by sacrificing many other sectors, especially TXA, CHM, AUT, and SRV. The breakdown of the sectoral value-added changes indicates the striking result that TRF and NTB-UK could succeed in protecting only FOD. Elsewhere, UK service sectors, such as ICT and SRV, would gain from the UK-EU27 border barriers because the primary factors in the contracting manufacturing sectors relocate to service sectors less seriously affected by the border barrier rises.

10 When we employ the CRS model, MCH would lose their output through Brexit, as shown in the Appendix. 
Figure 4.5: Value-added Change in the UK (top) and EU27 (bottom), Predicted by an IRS Model with the Lower NTB Sub-scenario

[Value Change, \% of UK and EU27 GDP]

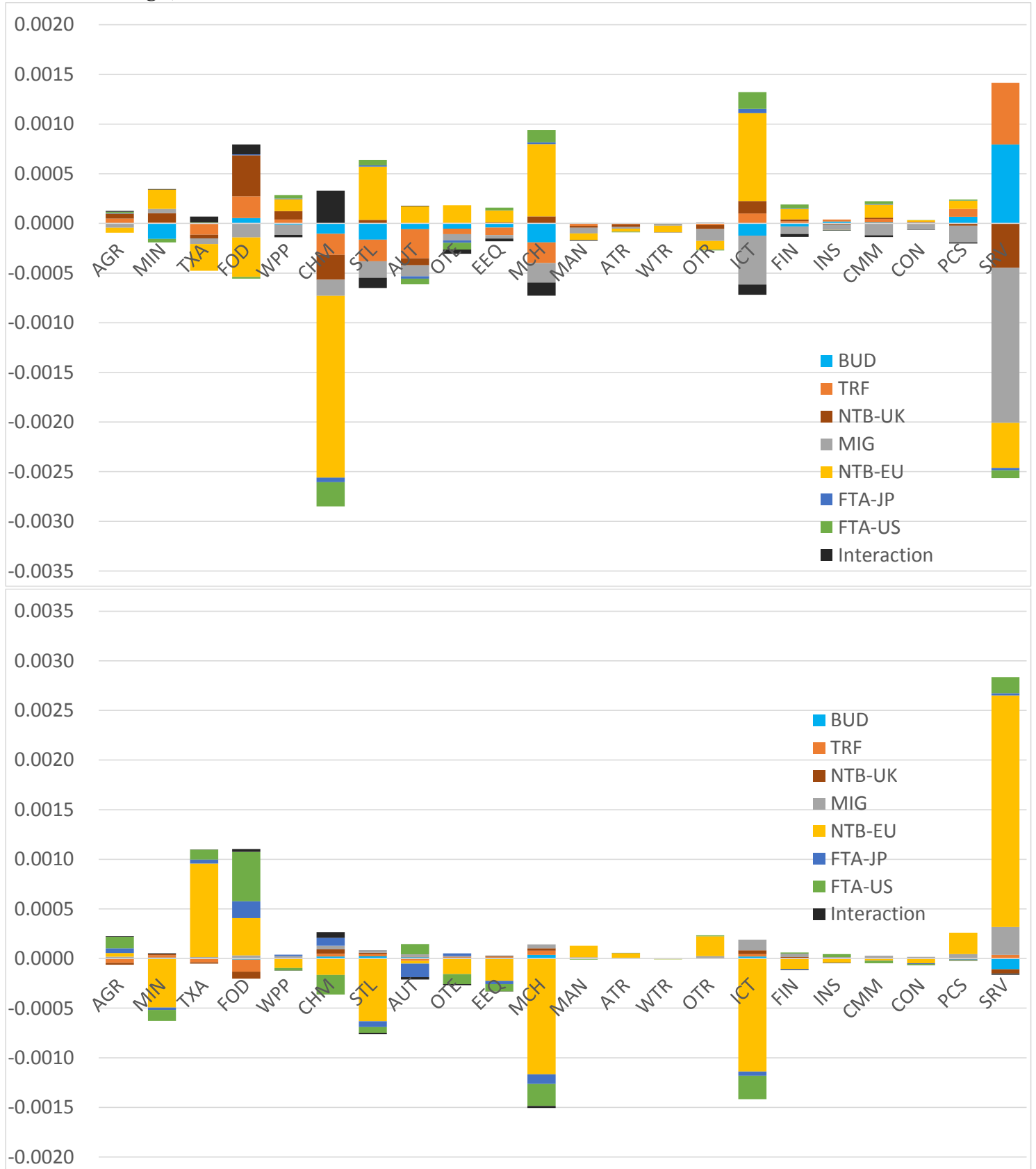

Note: Simulation results with the CRS model and/or with the upper NTB sub-scenario in the Appendix.

Returning migrants (MIG) would reduce labor availability in the UK. However, the labor loss would unevenly account for adverse impacts across the sectors. ICT and SRV would exhibit a marked decline reflecting their relatively high labor intensity. The manufacturing sectors would suffer from the labor loss in a smaller magnitude than ICT and SRV. The EU 
budget savings (BUD) would increase domestic household consumption, especially in SRV. As service sectors comprise about half of total household consumption, its impact on service output would be significant in the UK. At the same time, the budget savings would trigger an appreciation of the GBP, which would suppress the exports and output of many manufacturing sectors and ICT. The impact of MIG and BUD on sectoral output would demonstrate a sharp contrast between the UK and the EU27 in two aspects: qualitatively, these shocks would affect their sectoral outputs in opposite directions; quantitatively, as the EU27 economy is much larger, the output changes in the EU27 would not be as significant as for the UK.

Economic integration programs outside the UK (NTB-EU, FTA-JP, and FTA-US) would affect value-added differently across the UK industries. While TXA, FOD, CHM, and, SRV would suffer from these integration programs, STL, MCH, and ICT would gain. In the EU27, these three integration programs would improve allocative efficiency by intensifying concentration in its most competitive sectors (TXA, FOD, and SRV) by mobilizing primary factors from less competitive sectors (STL, MCH, and ICT). In turn, imports from the UK should compensate for any reduction in supply by these contracting sectors in the EU27. This substitution effect provides the UK with opportunities for exporting these particular goods and services. Among the three integration programs, FTA-JP would affect the EU27 only for FOD, CHM, and AUT and to a very limited extent, and therefore would propagate little to the UK.

\subsection{Macroeconomic Consequences}

Having analyzed the impact of Brexit at the industrial level, we examine its overall welfare impacts with Hicksian equivalent variations (EVs) by measuring the net household 
expenditure changes (Figure 4.6).11 The IRS model suggests that the UK would suffer a welfare loss of $1.1 \%$ from Brexit (ALL) with the lower NTB sub-scenario. In the upper NTB sub-scenario, the welfare loss would be as much as $1.5 \%$ of UK GDP. ${ }^{12}$ NTB-UK, MIG, and NTB-EU are the major negative factors for the UK, while BUD is the only positive effect. MIG would be the second-largest factor in the welfare impacts, even though it is only a minor consideration in the export impact (Figure 4.4). The following three transmission channels for MIG explain this somewhat counterintuitive result. One is the weak trade channel, as shown in Figure 4.4. The second is a transfer channel, whereby the transfer of labor endowment, worth $0.32 \%$ of UK GDP in total, to the EU27 directly reduces labor income in the UK. The third is that MIG makes the UK domestic labor market tighter and harms the competitiveness of its labor-intensive sectors, especially ICT and SRV. These service sectors would less likely decrease given the revised UK-EU27 trade barriers. They are therefore the most promising sectors left for the UK. However, MIG undermines the source of their competitiveness by reducing the labor endowments (Figure 4.5). Notably, the sum of these three negative impacts (TRF, NTB-UK, and MIG) would exceed the expected benefit from BUD, even without considering further integration programs by the EU27.13

11 As government consumption and investment uses are kept constant with fixed current account deficits (or foreign savings), the change in household expenditure is almost identical to the change in GDP.

12 Details are shown in the Appendix.

13 Even if we alternatively assume that the budget savings would be as large as $0.5 \%$ of UK GDP, it is obvious that the overall impact of Brexit would still be significantly negative for the UK. 
Figure 4.6: Welfare Impact of Brexit by Scenario Factors with the Lower NTB Sub-scenario [Equivalent Variations, \% of UK and EU27 GDP]

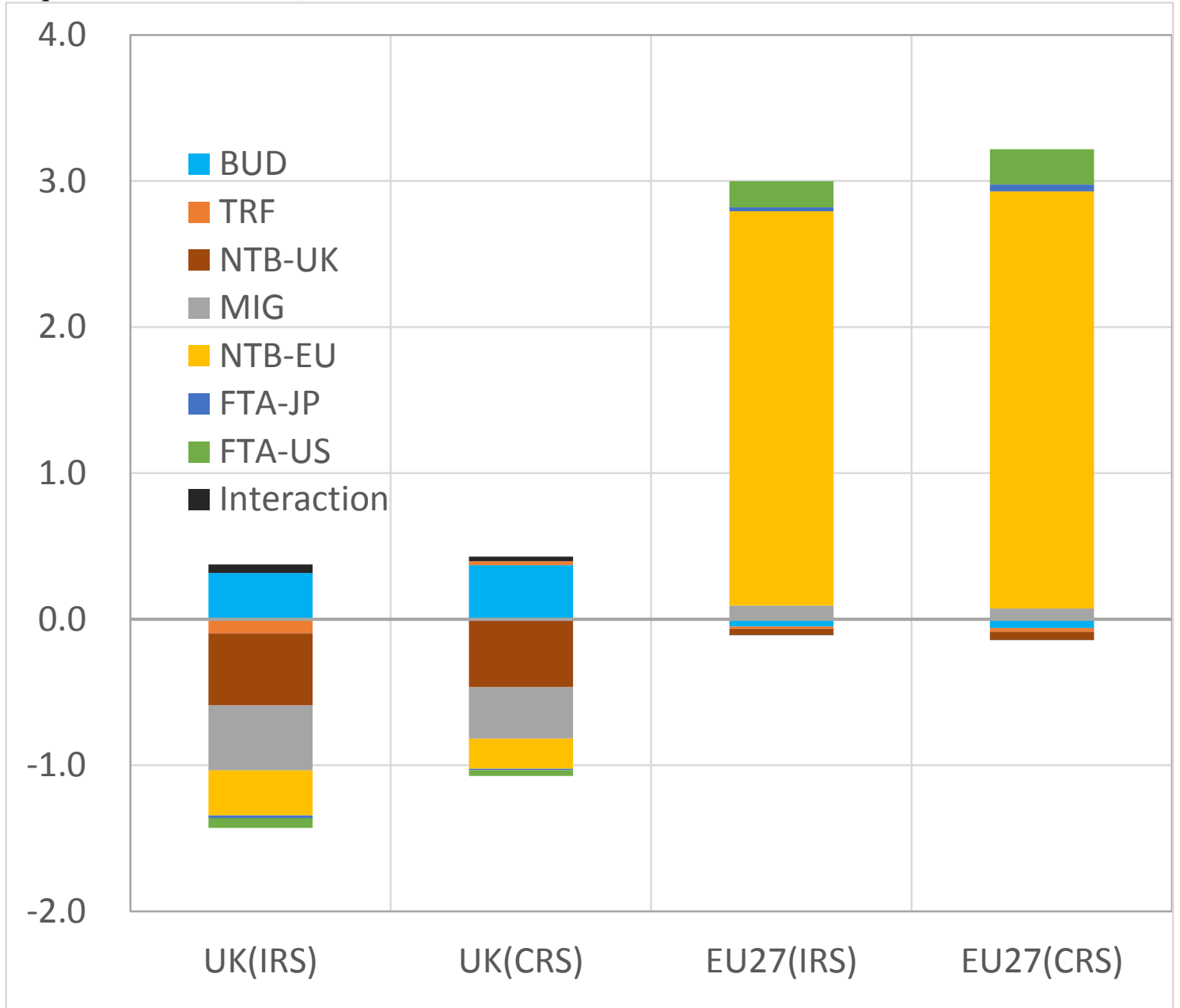

Note: Detailed results with the lower and upper NTB sub-scenarios are in the Appendix.

TRF would substantially reduce exports (Figure 4.4) but does not have a major negative effect on welfare. This is because TRF could improve welfare through a change in the terms of trade while harming the efficiency of resource allocation in the domestic economy. Nevertheless, the IRS model predicts that the terms-of-trade effect would be dominated by the distortionary effect, which tends to intensify, especially in manufacturing sectors with firm heterogeneity and love of variety. In contrast, the CRS model predicts a slight welfare gain from TRF by the dominant effect of the former. ${ }^{14}$ Even with this small gain from TRF

14 The UK's positive gain from the MFN tariff imposition becomes smaller with a larger Armington 
in combination with BUD, the CRS model consistently predicts an overall welfare loss from Brexit (ALL). Comparing the welfare impacts by these two models, the IRS model predicts a 60\% larger impact than the CRS model, although the seven IRS sectors currently account for only $11 \%$ and $16 \%$ of the UK and EU27 GDP, respectively.

Three direct negative shocks (BUD, TRF, and NTB-UK) would adversely affect the EU27 but would decrease its welfare by only $0.1 \%$ of EU27 GDP. This small impact is partly because the EU27 is not as dependent on the UK for trade and partly because the EU27 can maintain its size (six times larger in GDP and nine times larger in population) so that it can continue to enjoy economies of scale and sufficient variety through intra-EU27 trade even without the UK. Moreover, it is notable that the benefit of MIG would almost fully cancel out the combined losses. The marginal losses from these three direct negative shocks suggest that it would be more productive for the EU27 to focus on accelerating intra-EU27 integration and/or TTIP negotiation, rather than engaging in negotiations aimed at avoiding a hard Brexit.

\subsection{Sensitivity Analysis}

Our simulation results depend on the assumed parameters, especially the elasticity of substitution. In the IRS model case, our sensitivity analysis shows that a larger $\sigma_{i}^{A R M}$ and a smaller $\sigma_{i}^{M L Z}$ result in a more severe welfare deterioration for the UK (Figure 4.7). On the other hand, the EU27 would suffer under a smaller $\sigma_{i}^{A R M}$, while the effect of alternative values for $\sigma_{i}^{M L Z}$ on welfare is not clear. All CGE studies with the Melitz-type

elasticity $\sigma_{i}^{A R M}$, which weakens the terms-of-trade effect. When we assume $60 \%$ larger values for $\sigma_{i}^{A R M}$ in all the sectors of the CRS model, the welfare impact of TRF would become negative. 
IRS feature, to our best knowledge, used the same values for these two elasticities $\sigma_{i}^{A R M}$ and $\sigma_{i}^{M L Z}$, and collapsed the two-stage CES nests of the Armington composite and the variety composite into a one-stage CES nest, following the original specification by Melitz (2003).15 These models did not distinguish between the different roles of these elasticities or the nested structure, but jointly examined their impact with a single elasticity of substitution. Our sensitivity analysis shows that the two elasticities could affect welfare in different directions in our empirical setting. The CRS model, without the Melitz structure, allows us to examine only the effect of $\sigma_{i}^{A R M}$. We find its effect to be consistent with the results of many other CRS CGE analyses in that a larger $\sigma_{i}^{A R M}$ leads to larger welfare changes. The welfare impact would be much less sensitive to $\sigma_{i}^{A R M}$ in the CRS model than in the IRS model.

15 They followed Melitz's original model with a single-nest CES specification partly for model simplicity and partly for examination of the welfare impact equivalence with respect to the "trade elasticities" with CGE models, as suggested by Arkolakis et al. (2012). 
Figure 4.7: Sensitivity of Welfare Impact Estimates on the UK (top) and EU27 (bottom) with the Lower NTB Sub-scenario

[\% Point Changes from Welfare Impact in Figure 4.6]

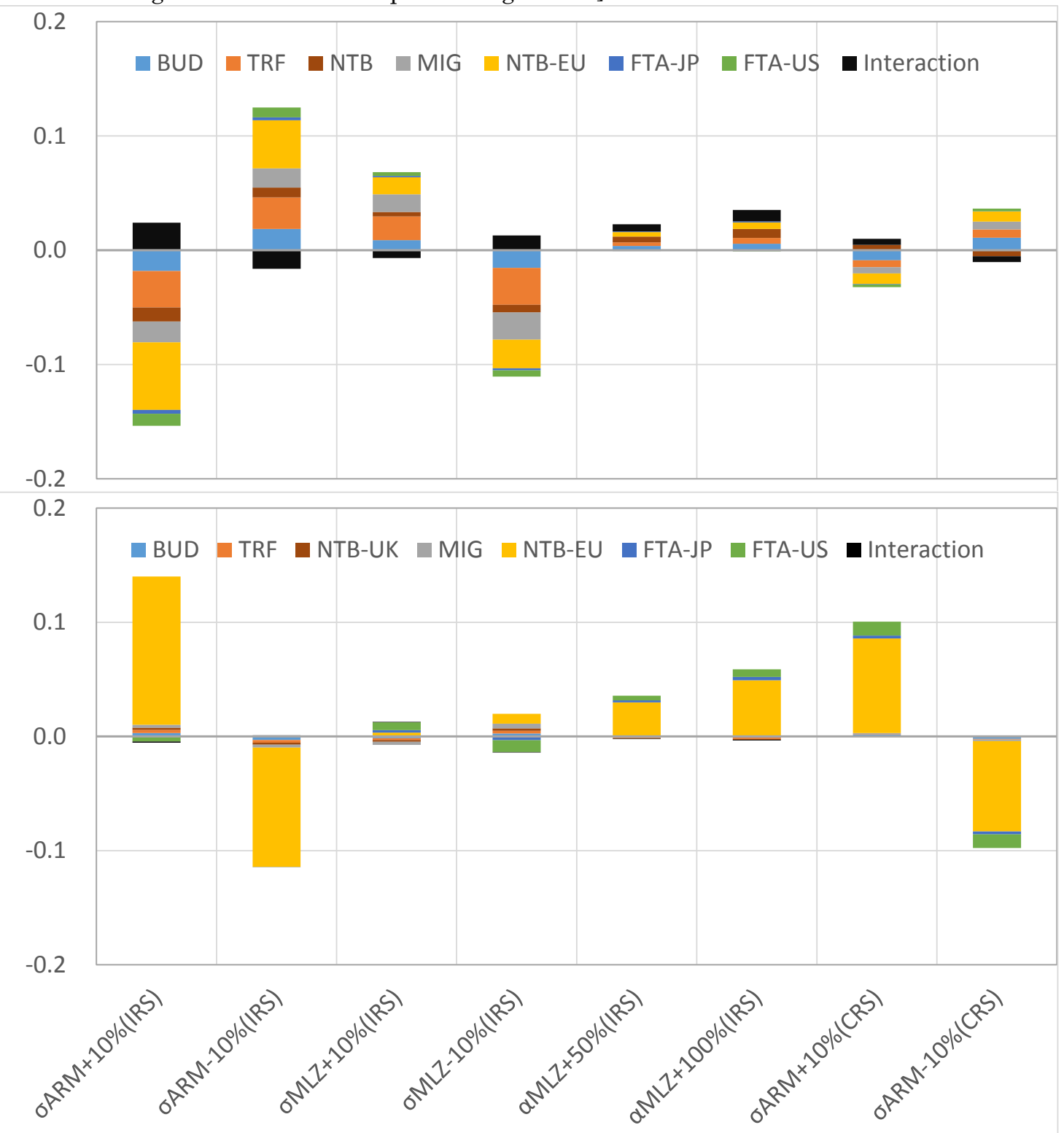

Note: Results of the sensitivity test with the upper NTB sub-scenario are in the Appendix

The Melitz model exploits the assumption of a Pareto distribution for the incidence of firm heterogeneity, which is represented by its shape parameter $\alpha^{M L Z}$. When we use $50 \%$ and $100 \%$ larger values for $\alpha^{M L Z}$ (i.e., greater firm heterogeneity), we identify a better welfare outcome, namely, a smaller loss for the UK and a larger gain for the EU27. Nevertheless, given this degree of parameter shifts, the deviations from the estimates in 
Figure 4.6 are not necessarily so marked.

\section{Concluding Remarks}

We conducted a Brexit impact analysis using a state-of-the-art CGE model with firm heterogeneity, which evokes productivity changes from firm exit and a loss of variety. The scope of our Brexit scenarios is limited to trade-related barriers that disconnect the UK from the remaining EU27 members and to future integration programs that leave the UK behind. In this sense, we should consider our impact estimates as lower bounds. Even so, the UK would significantly lose exports as large as $5.1-5.8 \%$ of GDP. It would also suffer a significant welfare deterioration, four times larger than the expected pecuniary benefit of the EU budget savings. Firm exit from export markets would also exacerbate any losses for the UK, as demonstrated by the IRS model with firm heterogeneity. Consequently, the total loss could be as much as $1.1 \%$ or $1.5 \%$ of UK GDP with the lower and upper NTB sub-scenarios, respectively. Even based on the conservative assumptions of Brexit shocks, our estimates of the welfare loss are consistent with or close to the lower side of the earlier estimates, which generally assume more shocks of greater magnitude.

UK voters may see these estimated economic losses as acceptable and reasonable given the cost of their sovereignty within the EU, and the freedom from regulations and bureaucracy enacted in the past by the European Commission. Nevertheless, their decisions must draw on accurate and comprehensive estimates of the costs and benefits of their policy options, for not only the Brexit referendum but also future post-Brexit negotiations. Our analysis provides detailed simulation results at the sectoral level, unlike earlier studies, which focused on aggregate indicators for convenience and the simplicity of presentation to voters. Such omissions limit the benefits of analysis using multisector models such as CGE models. We demonstrated that the gains and losses would indeed vary among sectors affected differently by direct and indirect Brexit shocks. Our results then enable richer policy 
discussions for reshaping the future European economy under alternative bilateral trade deals, like the Norway option, between the UK and the EU27. Although we would strongly advise the UK to seek opportunities to remain in the internal market as an affiliate member, which nevertheless requires it to make a partial budget contribution, the EU27 may be little interested in this in expectation of very limited gains from UK participation.

Our study focused on the trade-related factors in static models and did not consider any dynamic factors, such as domestic investment and FDI, which drive the European economy in the long run. An extension involving dynamic analysis with FDI, à la Hosoe (2014) for goods producers and Tarr (2013) for service providers, would enable us to describe the deceleration of trade fragmentation in Europe and to quantify the resulting long-run costs of Brexit. While our experiments assumed the returning migrants as an exogenous shock, we could also examine the impact of Brexit on immigration, as endogenously determined by economic environment and policy. We leave these possible extensions to future research. 


\section{Acknowledgements}

The author thanks Tomoki Ishikura for his helpful suggestions and gratefully acknowledges that this work was supported by JSPS KAKENHI Grant (No. 16K03613). The usual disclaimers apply.

\section{References}

Akgul, Z., Villoria, N. B., Hertel, T. W. (2010) "GTAP-HET: Introducing Firm Heterogeneity into the GTAP Model,” Journal of Global Economic Analysis 1(1), $111-180$.

Arkolakis, C., Costinot, A., Rodríguez-Clare, A. (2012) “New Trade Models, Same Old Gains?” American Economic Review 102(1), 94-130.

Armington, P. (1969) "A Theory of Demand for Products Distinguished by Place of Production," IMF Staff Papers 16(1), 159-178.

Aussilloux, V., Boumellassa, H., Emlinger, C., Fontagne, L. (2011) "The Economic Consequences for the UK and the EU of Completing the Single Market," BIS Economics Paper No. 11.

Balistreri, E. J., Hillberry, R. H., Rutherford, T. F. (2011) "Structural Estimation and Solution of International Trade Models with Heterogeneous Firms," Journal of International Economics 83(2), 95-108.

Balistreri, E. J., Rutherford, T. F. (2013) "Computing General Equilibrium Theories of Monopolistic Competition and Heterogeneous Firms," in: Dixon, P. B., Jorgenson, D. W., (eds.) Handbook of Computable General Equilibrium Modeling, Ch. 23, Vol. 1, Elsevier: pp. 1513-1570.

Bernard, A. B., Eaton, J., Jensen, J. B., Kortum, S. (2003) "Plants and Productivity in International Trade," American Economic Review 93(4), 1268-1290. 
Booth, S., Howarth, Ch. Persson, M., Ruparel, R., Swidlicki, P. (2015) "What If...? The Consequences, Challenges and Opportunities Facing Britain outside EU,” Open Europe Report 03/2015.

Boulanger, P., Philippidis, G. (2015) "The End of a Romance? A Note on the Quantitative Impacts of a 'Brexit' from the EU," Journal of Agricultural Economics 66(3), 832842.

Busch, B., Matthes, J. (2016) "Brexit-The Economic Impact: A Meta-Analysis," IW Report 10/2016, Institut der Deutschen Wirtschaft Köln.

Copenhagen Economics (2010) “Assessment of Barriers to Trade and Investment between the EU."

http://trade.ec.europa.eu/doclib/docs/2010/february/tradoc_145772.pdf (retrieved on June 19, 2017)

De Loecker, J., Goldberg, P. K., Khandelwal, A. M., Pavcnik, N. (2016) “Prices, Markups, and Trade Reform,” Econometrica 84 (2). 445-510.

Dhingra, S., Huang, H., Ottaviano, G., Pessoa, J. P., Sampson, T., Reenen, J. V. (2017) “The Costs and Benefits of Leaving the EU: Trade Effects," CEP Discussion Paper No. 1478, Centre for Economic Performance Technical Report, London School of Economics and Political Science.

Dixit, A., Stiglitz, J. E. (1977) "Monopolistic Competition and Optimum Product Variety," American Economic Review 67(3), 297-308.

Dixon, P., Jerie, M., Rimmer, M. (2016) "Modern Trade Theory for CGE Modelling: The Armington, Krugman and Melitz Models," Journal of Global Economic Analysis 1(1), $1-110$.

Ecorys (2009) "Non-Tariff Measures in EU-US Trade and Investment-An Economic Analysis," Reference: OJ 2007/S 180-219493.

Egger, P, Francois, J., Manchin, M., Nelson, D. (2015) "Non-tariff Barriers, Integration and the Transatlantic Economy," Economic Policy 30(83), 539-584. 
European Commission (2016) "Trade Sustainability Impact Assessment of the Free Trade Agreement between the European Union and Japan: Final Report." http://trade.ec.europa.eu/doclib/docs/2016/may/tradoc_154522.pdf $\quad$ (retrieved on June 19, 2017)

Hertel, T. W. (ed.) (1997) Global Trade Analysis: Modeling and Applications, Cambridge University Press.

HM Treasury (2013) “European Union Finances 2013, Statement on the 2013 EU Budget and Measures to Counter-fraud and Financial Mismanagement," November, The Stationery Office, London.

Hosoe, N. (2014) “Japanese Manufacturing Facing Post-Fukushima Power Crisis: A Dynamic Computable General Equilibrium Analysis with Foreign Direct Investment," Applied Economics 46(17), 2010-2020.

Hosoe, N., Gasawa, K., Hashimoto, H. (2010) Textbook of Computable General Equilibrium Modelling Programming and Simulations, Palgrave.

Inagaki, K. (2016) "Japan Carmakers Weigh UK Options Post-Brexit: Non-EU Levy Could Prompt Exodus of Automakers, Analysts Warn," Financial Times, June 27. https://next.ft.com/content/1bef35ac-3c44-11e6-8716-a4a71e8140b0 (retrieved on July 29, 2016)

Itakura, K., Oyamada, K. (2015) “Examining Trade Response of Armington-Krugman-Melitz Encompassing Module in a CGE Model," paper presented at the 18th Annual Conference on Global Economic Analysis, Melbourne, Australia. https://www.gtap.agecon.purdue.edu/resources/res_display.asp?RecordID=4666 (retrieved on August 12, 2016)

Jafari, Y., Britz, W. (2017) “Brexit-An Economy־wide Impact Assessment Looking into Trade, Immigration, and Foreign Direct Investment," Paper Presented at the $20^{\text {th }}$ Annual Conference on Global Economic Analysis, June 7-9. 
Kirkegaard, J. F. (2017) "How to Make Immigration the Bridge to an Orderly and Timely Brexit," Policy Brief 17-17, Peterson Institute for International Economics, Washington, DC.

Latorre, M. C., Yonezawa, H. (2017) "Stopped TTIP?: Its Potential Impact on the World and the Role of Neglected FDI,” MPRA Paper No. 77162.

Melitz, M. J. (2003) "The Impact of Trade on Intra-Industry Reallocations and Aggregate Industry Productivity," Econometrica 71(6), 1695-1725.

Núñez Ferrer, J., Rinaldi, D. (2016) "The Impact of Brexit on the EU Budget: A Noncatastrophic Event," CEPS Policy Brief No. 347.

Tarr, D. G. (2013) "Putting Services and Foreign Direct Investment with Endogenous Productivity Effects in Computable General Equilibrium Models,” in: Dixon, P. B., Jorgenson, D. W. (eds.) Handbook of Computable General Equilibrium Modeling; Ch. 6, Vol. 1, Elsevier: pp. 303-377.

OECD (2016) "The Economic Consequences of Brexit: A Taxing Decision," OECD Economic Policy Papers No. 16.

PwC (2016) "Leaving the EU: Implications for the UK Economy," March. http://news.cbi.org.uk/news/leaving-eu-would-cause-a-serious-shock-to-ukeconomy-new-pwc-analysis/leaving-the-eu-implications-for-the-uk-economy/ (retrieved on July 27, 2016)

Walmsley, T., Ahmed, S. A., Parsons, S. (2005) "The GMig2 Data Base: A Data Base of Bilateral Labor Migration, Wages and Remittances," GTAPResearch Memorandum No. 6.

Zhai, F. (2008) "Armington Meets Melitz: Introducing Firm Heterogeneity in a Global CGE Model of Trade," Journal of Economic Integration 23(3), 575-604. 


\section{Appendix Tables and Figures Omitted in Main Text}

The assumed MFN import tariff rates used in TRF for all EU regions are in Table A.1. The upper NTB sub-scenario, used in NTB-UK, NTB-EU, FTA-US, and FTA-JP, is in Table A.2, while the lower NTB sub-scenario is in Table 3.3.

Table A.1: EU MFN Import Tariff Rates by Origin, Good, and Destination $[\%]$

\begin{tabular}{|c|c|c|c|c|c|c|c|c|c|c|}
\hline & & BNL & OEU & FRA & DEU & ITA & POL & ESP & SWE & GBR \\
\hline \multirow[t]{12}{*}{ JPN } & AGR & 3.2 & 2.7 & 5.3 & 2.5 & 4.3 & 2.8 & 5.1 & 1.9 & 3. \\
\hline & MIN & 0.0 & 0.2 & 0.1 & 0.2 & 0.6 & 0.0 & 0.1 & 0.5 & 0.3 \\
\hline & TXA & 5.2 & 6.0 & 6.0 & 5.1 & 6.5 & 5.3 & 6.5 & 5.8 & 6. \\
\hline & FOD & 9.5 & 10.8 & 11.1 & 8.1 & 9.8 & 11.3 & 9.9 & 10.0 & 8.1 \\
\hline & WPP & 0.7 & 0.4 & 0.2 & 0.5 & 0.2 & 0.5 & 2.0 & 0.2 & 1. \\
\hline & CHM & 3.6 & 2.9 & 3.6 & 3.3 & 3.5 & 2.5 & 3.1 & 4.6 & 3. \\
\hline & STL & 1.7 & 2.5 & 2.7 & 1.7 & 1.6 & 2.0 & 2.5 & 3.7 & 0. \\
\hline & AUT & 8.3 & 7.2 & 7.7 & 7.1 & 8.5 & 6.7 & 8.1 & 8.2 & 6. \\
\hline & OTE & 5.4 & 3.1 & 5.0 & 2.7 & 4.1 & 2.6 & 5.2 & 2.9 & 2. \\
\hline & EEQ & 2.0 & 1.5 & 2.5 & 1.8 & 1.3 & 2.7 & 2.5 & 2.7 & $2 .^{\prime}$ \\
\hline & $\mathrm{MCH}$ & 1.9 & 1.9 & 2.0 & 2.0 & 1.9 & 2.0 & 2.0 & 1.9 & 1.8 \\
\hline & MAN & 1.8 & 2.6 & 2.7 & 1.1 & 3.4 & 1.7 & 3.0 & 2.9 & 1.5 \\
\hline \multirow[t]{11}{*}{ USA } & AGR & 2.7 & 3.2 & 3.0 & 2.8 & 4.4 & 6.1 & 3.1 & 3.1 & 3. \\
\hline & TXA & 6.2 & 6.6 & 7.2 & 6.7 & 4.7 & 5.1 & 7.0 & 8.5 & 8. \\
\hline & FOD & 16.6 & 12.5 & 11.2 & 13.9 & 16.2 & 7.0 & 14.1 & 11.9 & 11.2 \\
\hline & WPP & 0.0 & 0.5 & 0.3 & 0.3 & 0.1 & 0.1 & 0.3 & 0.2 & 0. \\
\hline & $\mathrm{CHM}$ & 2.5 & 2.0 & 2.0 & 2.0 & 1.6 & 2.9 & 1.6 & 1.5 & 2. \\
\hline & STL & 1.9 & 2.2 & 3.1 & 1.9 & 0.9 & 2.0 & 2.4 & 1.7 & $1 . '$ \\
\hline & AUT & 7.3 & 7.6 & 5.2 & 9.1 & 6.7 & 7.7 & 5.8 & 5.7 & 4.1 \\
\hline & OTE & 1.9 & 1.3 & 1.0 & 1.2 & 1.3 & 1.3 & 1.0 & 1.3 & 0. \\
\hline & EEQ & 0.5 & 0.4 & 0.6 & 0.5 & 0.7 & 0.6 & 0.5 & 0.8 & 0. \\
\hline & $\mathrm{MCH}$ & 1.0 & 1.3 & 1.2 & 1.3 & 1.5 & 1.4 & 1.2 & 1.0 & 1. \\
\hline & MAN & 1.2 & 1.6 & 0.9 & 1.4 & 1.0 & 2.5 & 1.3 & 1.9 & 0.6 \\
\hline \multirow[t]{11}{*}{ ROW } & AGR & 1.8 & 2.3 & 2.9 & 1.7 & 2.2 & 2.5 & 2.6 & 1.8 & 2. \\
\hline & TXA & 6.8 & 6.5 & 6.8 & 6.2 & 5.3 & 6.1 & 6.3 & 6.8 & 7. \\
\hline & FOD & 15.0 & 9.5 & 6.5 & 11.8 & 9.5 & 5.2 & 6.9 & 10.7 & 12.0 \\
\hline & WPP & 0.5 & 0.5 & 0.3 & 0.3 & 0.3 & 0.6 & 0.4 & 0.2 & 0. \\
\hline & $\mathrm{CHM}$ & 1.0 & 0.6 & 0.7 & 1.0 & 0.9 & 1.3 & 0.8 & 0.8 & 1. \\
\hline & STL & 0.7 & 0.8 & 1.3 & 0.7 & 0.5 & 1.2 & 0.9 & 0.7 & 0. \\
\hline & AUT & 3.1 & 2.1 & 1.7 & 1.7 & 2.3 & 2.1 & 2.9 & 2.0 & 2. \\
\hline & OTE & 3.3 & 1.0 & 0.7 & 0.7 & 1.4 & 0.6 & 1.2 & 1.5 & 1.2 \\
\hline & EEQ & 0.9 & 0.9 & 1.1 & 0.8 & 0.7 & 1.0 & 1.0 & 0.6 & 1. \\
\hline & $\mathrm{MCH}$ & 0.9 & 1.1 & 1.0 & 0.9 & 1.2 & 0.9 & 1.1 & 0.8 & 1. \\
\hline & MAN & 0.8 & 1.7 & 1.4 & 1.3 & 1.5 & 2.1 & 2.0 & 1.6 & 1. \\
\hline
\end{tabular}

Source: GTAP Database version 9A. 
Table A.2: Assumed Change of NTBs in the Upper NTB Sub-scenario [\% Point]

\begin{tabular}{|c|c|c|c|c|c|c|c|c|c|c|c|c|c|}
\hline $\begin{array}{l}\text { From: } \\
\text { To: }\end{array}$ & $\begin{array}{l}\text { EU } \\
\text { BNL }\end{array}$ & $\begin{array}{c}\text { EU } \\
\text { OEU }\end{array}$ & $\begin{array}{c}\text { EU } \\
\text { FRA }\end{array}$ & $\begin{array}{l}\text { EU } \\
\text { DEU }\end{array}$ & $\begin{array}{l}\text { EU } \\
\text { ITA }\end{array}$ & $\begin{array}{l}\text { EU } \\
\text { POL }\end{array}$ & $\begin{array}{l}\text { EU } \\
\text { ESP }\end{array}$ & $\begin{array}{l}\text { EU } \\
\text { SWE }\end{array}$ & $\begin{array}{l}\text { EU27/GBR } \\
\text { GBR/EU27 }\end{array}$ & $\begin{array}{l}\text { EU27 } \\
\text { JPN }\end{array}$ & $\begin{array}{l}\text { EU27 } \\
\text { USA }\end{array}$ & $\begin{array}{l}\text { JPN } \\
\text { EU27 }\end{array}$ & $\begin{array}{c}\text { USA } \\
\text { EU27 }\end{array}$ \\
\hline AGR & -13.8 & -15.5 & -15.1 & -16.8 & -17.0 & -16.8 & -16.2 & -16.0 & & & & & \\
\hline TXA & -20.0 & -22.9 & -22.3 & -22.0 & -22.5 & -23.0 & -23.1 & -22.4 & 2.4 & & -9.0 & & -6.5 \\
\hline FOD & -24.2 & -31.8 & -31.9 & -31.9 & -32.5 & -31.9 & -32.4 & -31.2 & 7.5 & -9.0 & -37.4 & & -20.8 \\
\hline WPP & -0.9 & -2.8 & -1.5 & -4.2 & -2.7 & -2.8 & -4.2 & -4.7 & 1.7 & -10.6 & -4.7 & & -4.7 \\
\hline CHM & -16.1 & -22.2 & -20.2 & -21.7 & -21.4 & -22.8 & -22.1 & -21.0 & 3.8 & -20.0 & -12.0 & -7.3 & -9.2 \\
\hline STL & -0.9 & -2.1 & -0.9 & -2.5 & -2.3 & -2.8 & -2.3 & -3.1 & 1.9 & -6.5 & -8.5 & -1.9 & -2.7 \\
\hline AUT & -0.7 & -1.3 & -1.1 & -1.9 & -1.6 & -1.0 & -1.1 & -1.7 & 3.0 & -3.8 & -11.3 & -3.5 & -8.2 \\
\hline OTE & -1.7 & -6.7 & -1.1 & -1.8 & -2.7 & -1.3 & -3.3 & -4.5 & 2.8 & -41.0 & -9.7 & -3.1 & -6.2 \\
\hline EEQ & -2.0 & -2.7 & -2.8 & -4.4 & -4.6 & -2.3 & -5.2 & -6.9 & 0.7 & -3.9 & -2.5 & -1.7 & -1.7 \\
\hline $\mathrm{MCH}$ & -2.1 & -3.0 & -2.4 & -4.8 & -3.7 & -2.6 & -4.0 & -5.2 & & -3.9 & & & \\
\hline MAN & -20.1 & -27.8 & -29.1 & -27.7 & -28.5 & -27.5 & -28.3 & -25.3 & & & & & \\
\hline ATR & -6.8 & -6.7 & -7.1 & -8.8 & -7.8 & -6.8 & -5.8 & -8.2 & & -1.3 & & -0.4 & \\
\hline WTR & -18.6 & -17.6 & -19.4 & -19.4 & -20.9 & -19.0 & -17.2 & -20.3 & & -5.2 & & -1.4 & \\
\hline OTR & -6.8 & -6.7 & -7.1 & -8.8 & -7.8 & -6.8 & -5.8 & -8.2 & & & & & \\
\hline ICT & -10.3 & -10.0 & -9.6 & -12.5 & -12.0 & -10.7 & -10.9 & -11.8 & 1.3 & -3.7 & -1.7 & -2.5 & -2.9 \\
\hline FIN & -12.8 & -12.3 & -10.2 & -12.7 & -12.4 & -12.2 & -12.2 & -12.8 & 1.4 & -8.7 & -17.4 & -2.9 & -2.3 \\
\hline INS & -21.2 & -21.1 & -19.3 & -21.4 & -21.9 & -21.1 & -21.3 & -21.4 & 1.4 & -1.2 & -9.2 & -2.8 & -2.8 \\
\hline CMM & -10.4 & -10.4 & -9.4 & -11.5 & -11.8 & -10.5 & -10.7 & -12.4 & 2.0 & -19.2 & -1.1 & -4.3 & -4.3 \\
\hline $\mathrm{CON}$ & -12.5 & -12.3 & -10.2 & -17.6 & -13.7 & -13.8 & -13.0 & -15.5 & 0.4 & -1.9 & -1.4 & -1.9 & -1.3 \\
\hline PCS & -12.5 & -12.4 & -11.9 & -14.3 & -13.6 & -12.5 & -11.8 & -13.7 & 0.4 & -3.7 & -1.2 & -1.0 & -0.6 \\
\hline SRV & -12.5 & -12.4 & -11.9 & -14.3 & -13.6 & -12.5 & -11.8 & -13.7 & & & & & \\
\hline
\end{tabular}

Source: Ecorys (2009), Copenhagen Economics (2010), Aussilloux et al. (2011), and author's assumption.

The details of the welfare impact prediction are in Table A.3 and graphically presented in Figure 4.6 with the lower NTB sub-scenario. This table shows that the upper NTB sub-scenario would lead to a larger welfare loss for the UK and a larger gain for the EU27.

Table A.3: Details of Welfare Impact in EVs UK Lower NTB Upper NTB Lower NTB EU27 [mil. USD] [\% of GDP] [mil. USD] [\% of GDP] [mil. USD] [\% of GDP] [mil. USD] [\% of GDP]

\begin{tabular}{lrrrrrrrr}
\hline & \multicolumn{7}{c}{ IRS Model Estimate } \\
\hline ALL & $-24,055$ & $(-1.06)$ & $-34,302$ & $(-1.51)$ & 406,891 & $(2.89)$ & 691,307 & $(4.91)$ \\
\hline BUD & 7,221 & $(0.32)$ & $\leftarrow$ & $\leftarrow$ & $-7,094$ & $(-0.05)$ & $\leftarrow$ & $\leftarrow$ \\
TRF & $-2,209$ & $(-0.10)$ & $\leftarrow$ & $\leftarrow$ & $-2,127$ & $(-0.02)$ & $\leftarrow$ & $\leftarrow$ \\
NTB-UK & $-11,277$ & $(-0.49)$ & $-17,563$ & $(-0.77)$ & $-6,061$ & $(-0.04)$ & $-9,785$ & $(-0.07)$ \\
MIG & $-10,089$ & $(-0.44)$ & $\leftarrow$ & $\leftarrow$ & 13,056 & $(0.09)$ & $\leftarrow$ & $\leftarrow$ \\
NTB-EU & $-7,047$ & $(-0.31)$ & $-11,404$ & $(-0.50)$ & 380,311 & $(2.70)$ & 650,852 & $(4.62)$ \\
FTA-JP & -415 & $(-0.02)$ & -547 & $(-0.02)$ & 3,868 & $(0.03)$ & 6,463 & $(0.05)$ \\
FTA-US & $-1,545$ & $(-0.07)$ & $-2,342$ & $(-0.10)$ & 25,140 & $(0.18)$ & 40,587 & $(0.29)$ \\
Interaction & 1,306 & $(0.06)$ & 2,631 & $(0.12)$ & -202 & $(-0.00)$ & -645 & $(-0.00)$
\end{tabular}

\begin{tabular}{lrrrrrrrrr}
\multicolumn{10}{c}{ CRS Model Estimate } \\
\hline ALL & $-14,706$ & $(-0.65)$ & $-23,465$ & $(-1.03)$ & 433,325 & $(3.08)$ & 731,405 & $(5.19)$ \\
\hline BUD & 8,441 & $(0.37)$ & $\leftarrow$ & $\leftarrow$ & $-8,692$ & $(-0.06)$ & $\leftarrow$ & $\leftarrow$ \\
TRF & 615 & $(0.03)$ & $\leftarrow$ & $\leftarrow$ & $-3,329$ & $(-0.02)$ & $\leftarrow$ & $\leftarrow$ \\
NTB-UK & $-10,599$ & $(-0.47)$ & $-16,557$ & $(-0.73)$ & $-7,848$ & $(-0.06)$ & $-12,505$ & $(-0.09)$ \\
MIG & $-8,048$ & $(-0.35)$ & $\leftarrow$ & $\leftarrow$ & 10,255 & $(0.07)$ & $\leftarrow$ & $\leftarrow$ \\
NTB-EU & $-4,690$ & $(-0.21)$ & $-7,628$ & $(-0.33)$ & 402,409 & $(2.86)$ & 681,575 & $(4.84)$ \\
FTA-JP & -189 & $(-0.01)$ & -250 & $(-0.01)$ & 6,558 & $(0.05)$ & 9,372 & $(0.07)$ \\
FTA-US & -943 & $(-0.04)$ & $-1,471$ & $(-0.06)$ & 34,080 & $(0.24)$ & 55,475 & $(0.39)$ \\
Interaction & 707 & $(0.03)$ & 1,433 & $(0.06)$ & -108 & $(-0.00)$ & -746 & $(-0.01)$
\end{tabular}


Larger NTB changes would impact exports and the number of firms more significantly in most sectors, while the impacts on sectors with more marginal changes may flip (e.g., WPP and MCH of the UK in Figure A.1; and MCH in the UK and AUT and MAN in the EU27 in Figure A.2). Similar observations are made by comparing Figure 4.3 (the lower NTB sub-scenario) with Figure A.5 (the upper NTB sub-scenario), where the IRS model is used consistently. The CRS model prediction in Figure A.3 is smaller than the IRS model prediction in Figure 4.3. It is notable that CHM, which benefited most from Brexit in the EU27 by the IRS model prediction, would have a smaller gain than FOD in the CRS model prediction. This indicates that firm heterogeneity plays a crucial role in the prediction of the trade impact, especially on CHM. 
Figure A.1: Total Impact of Brexit (ALL) on UK-EU27 Bilateral Exports with the Upper NTB Sub-scenario

[\% Change from Base]

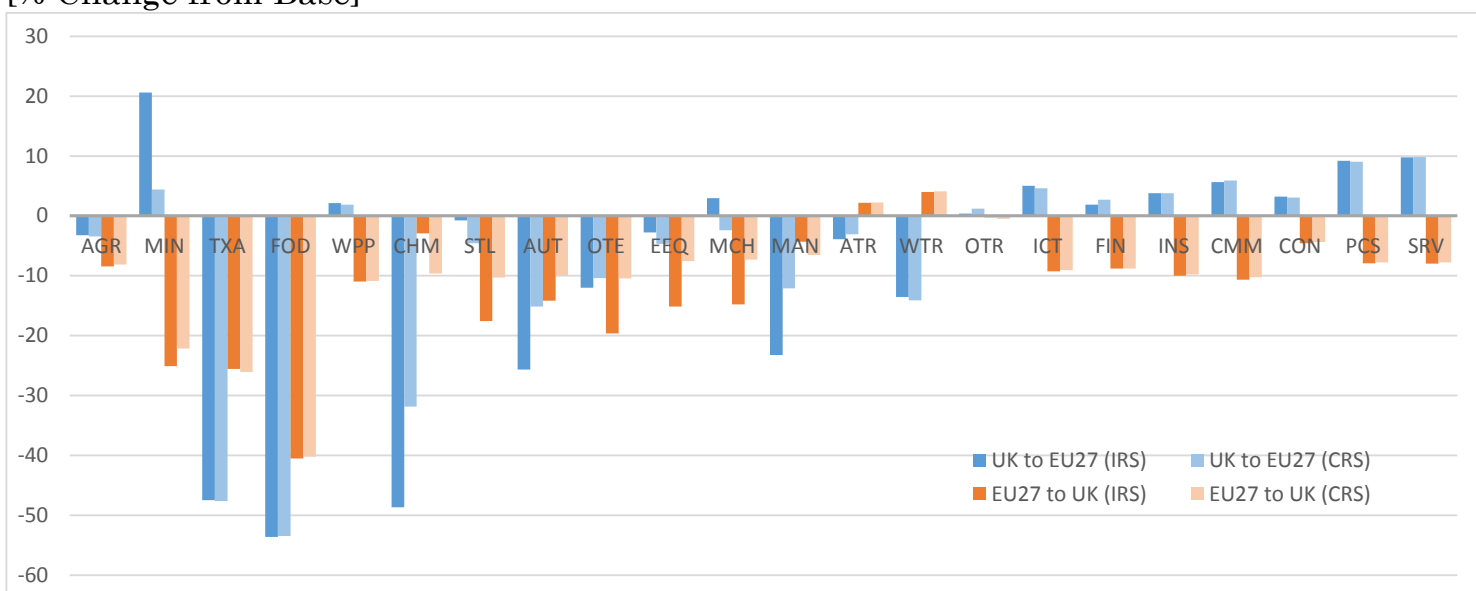

[Export Value Change, \% of UK GDP]

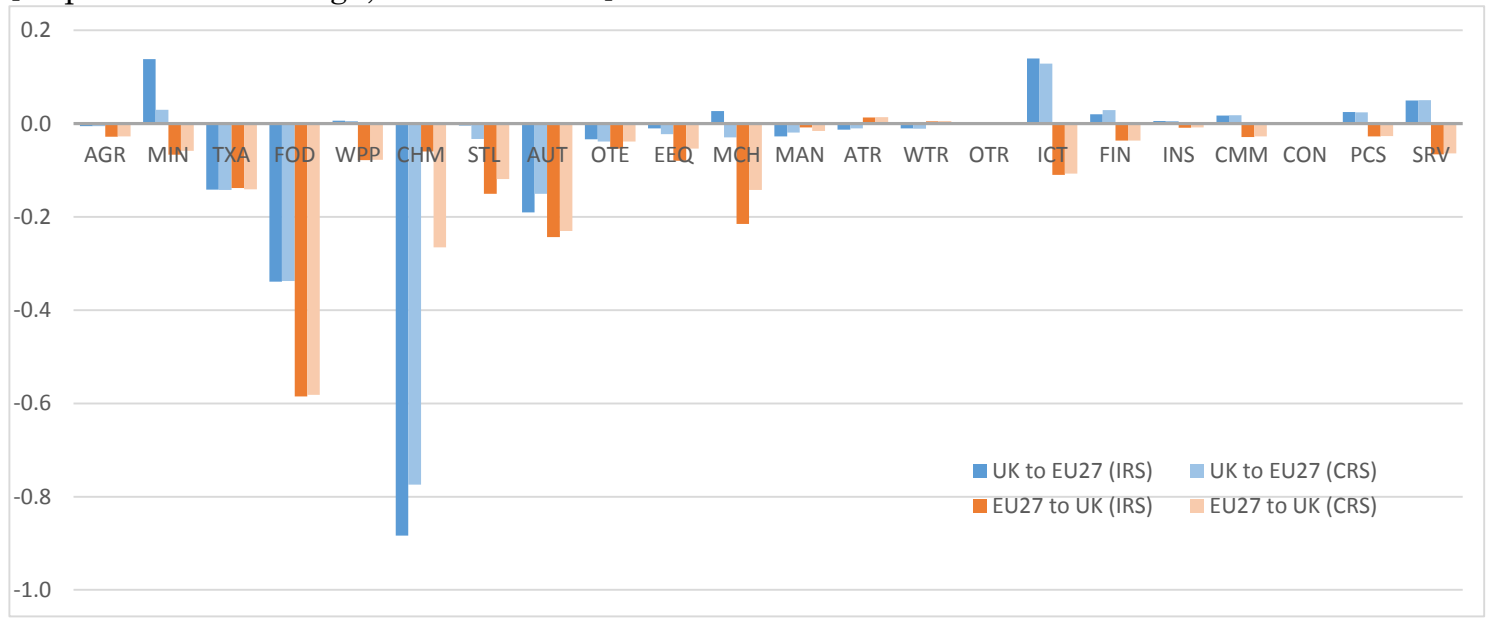


Figure A.2: Impact of Brexit (ALL) on Number of Firms by Supply Destination in the UK (top) and EU27 (bottom) with the Upper NTB Sub-scenario [\% Change from Base]

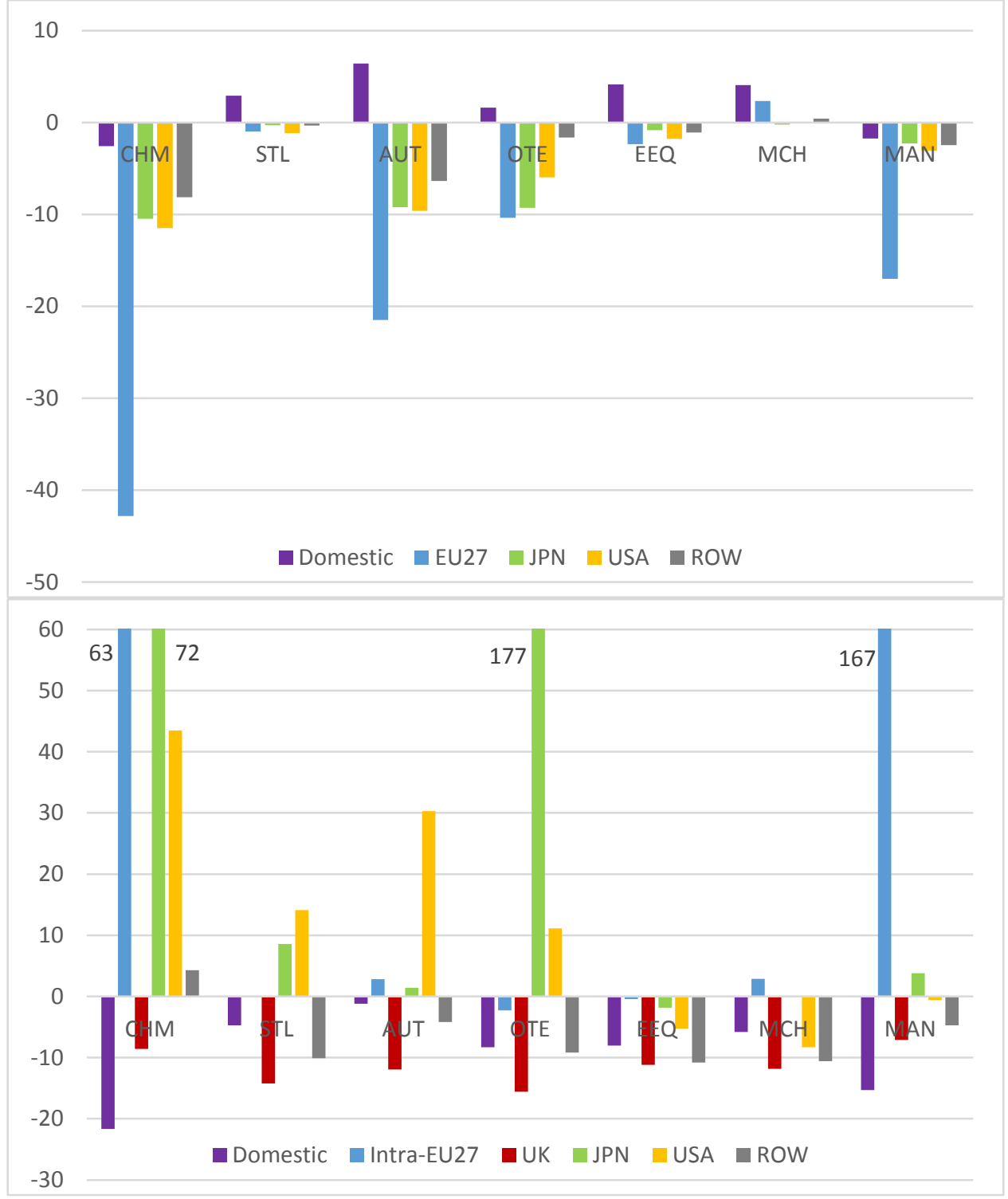


Figure A.3: Impact of Brexit (ALL) on Exports by the UK (top) and EU27 (bottom) by Direction Predicted by a CRS Model with the Lower NTB Sub-scenario

[Export Value Change, \% of UK and EU27 GDP]

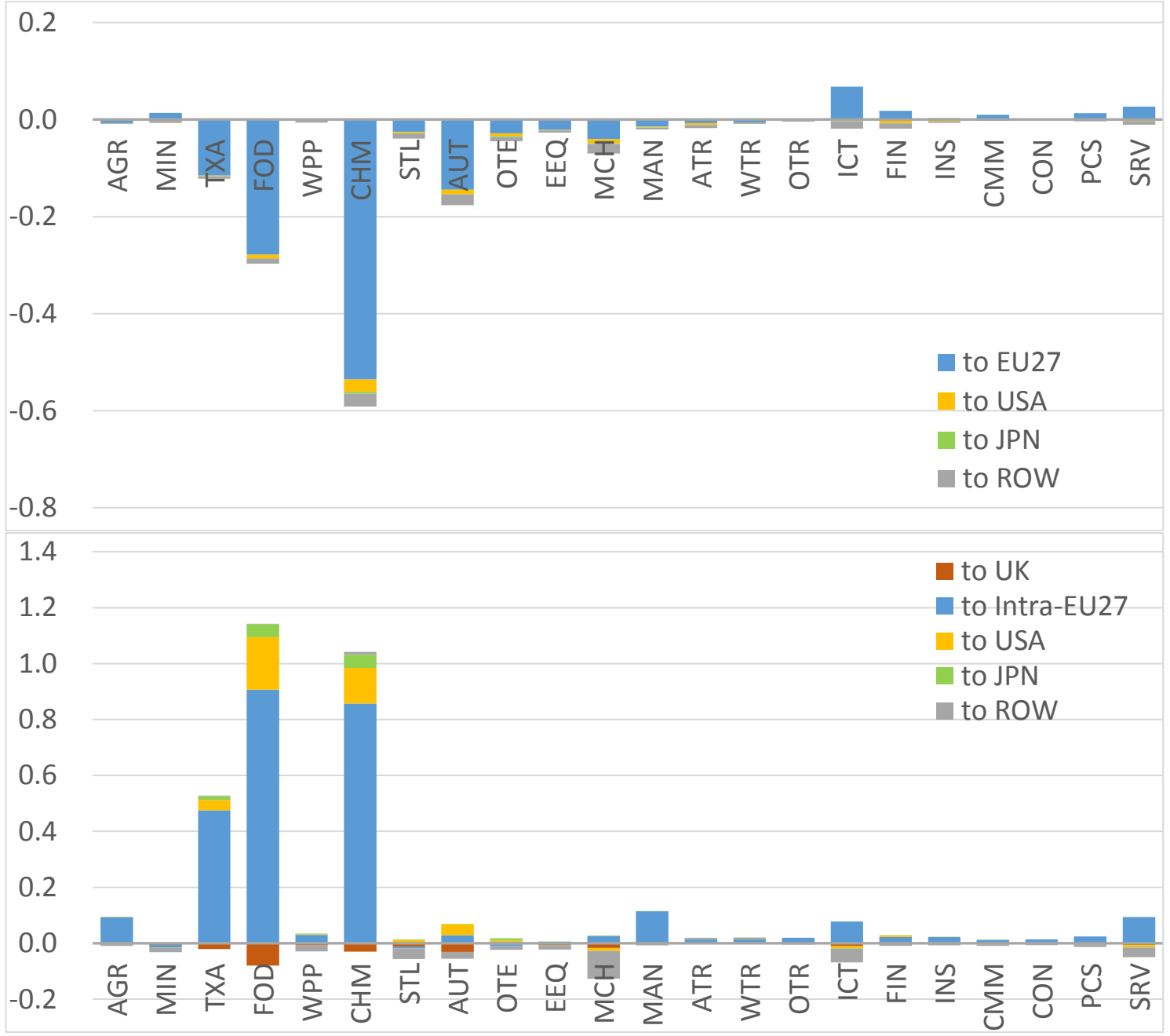


Figure A.4: Impact of Brexit (ALL) on Exports by the UK (top) and EU27 (bottom) by Direction Predicted by a CRS Model with the Upper NTB Sub-scenario

[Export Value Change, \% of UK and EU27 GDP]

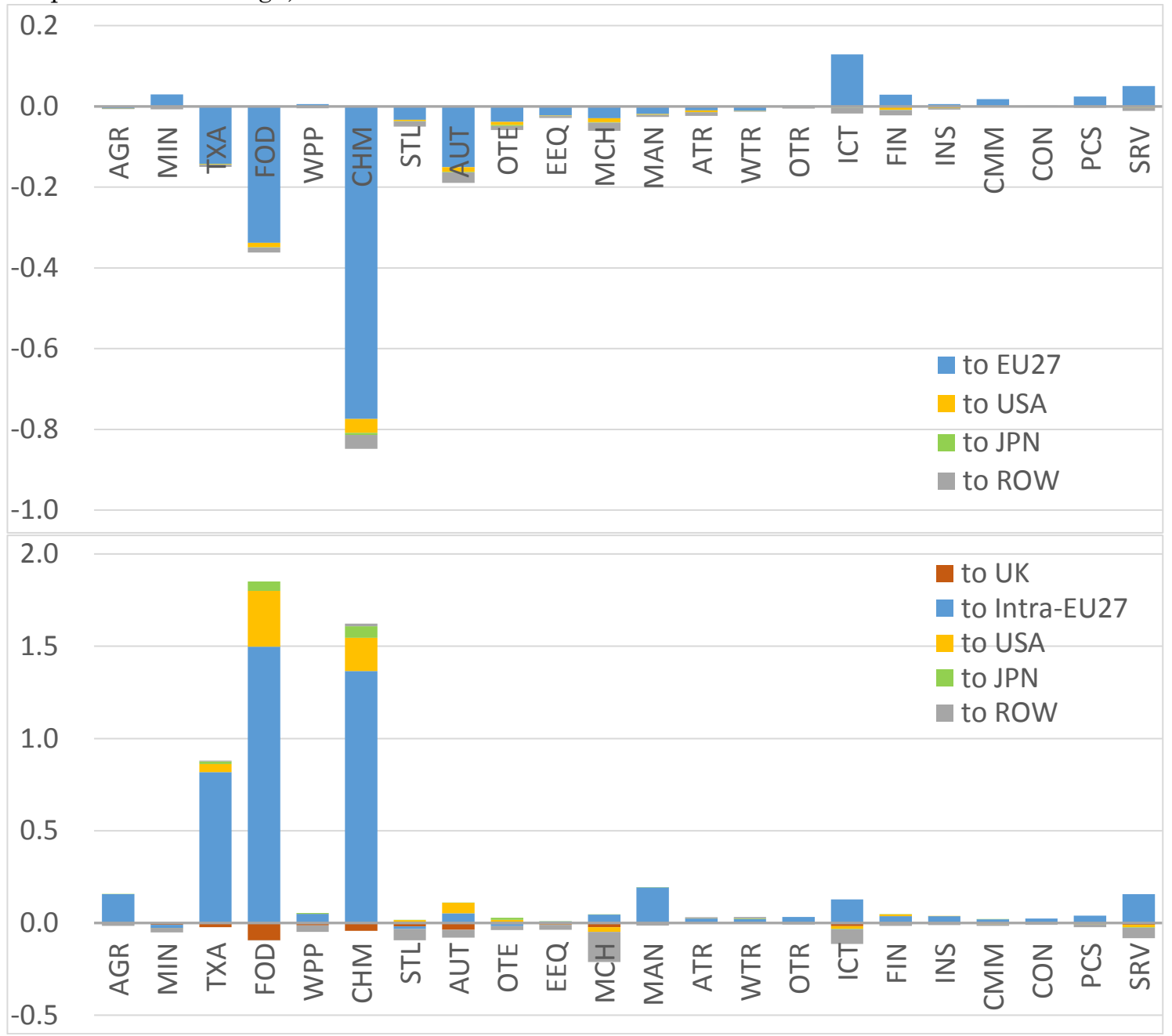


Figure A.5: Impact of Brexit (ALL) on Exports by the UK (top) and EU27 (bottom) by Direction Predicted by an IRS Model with the Upper NTB Sub-scenario [Export Value Change, \% of UK and EU27 GDP]

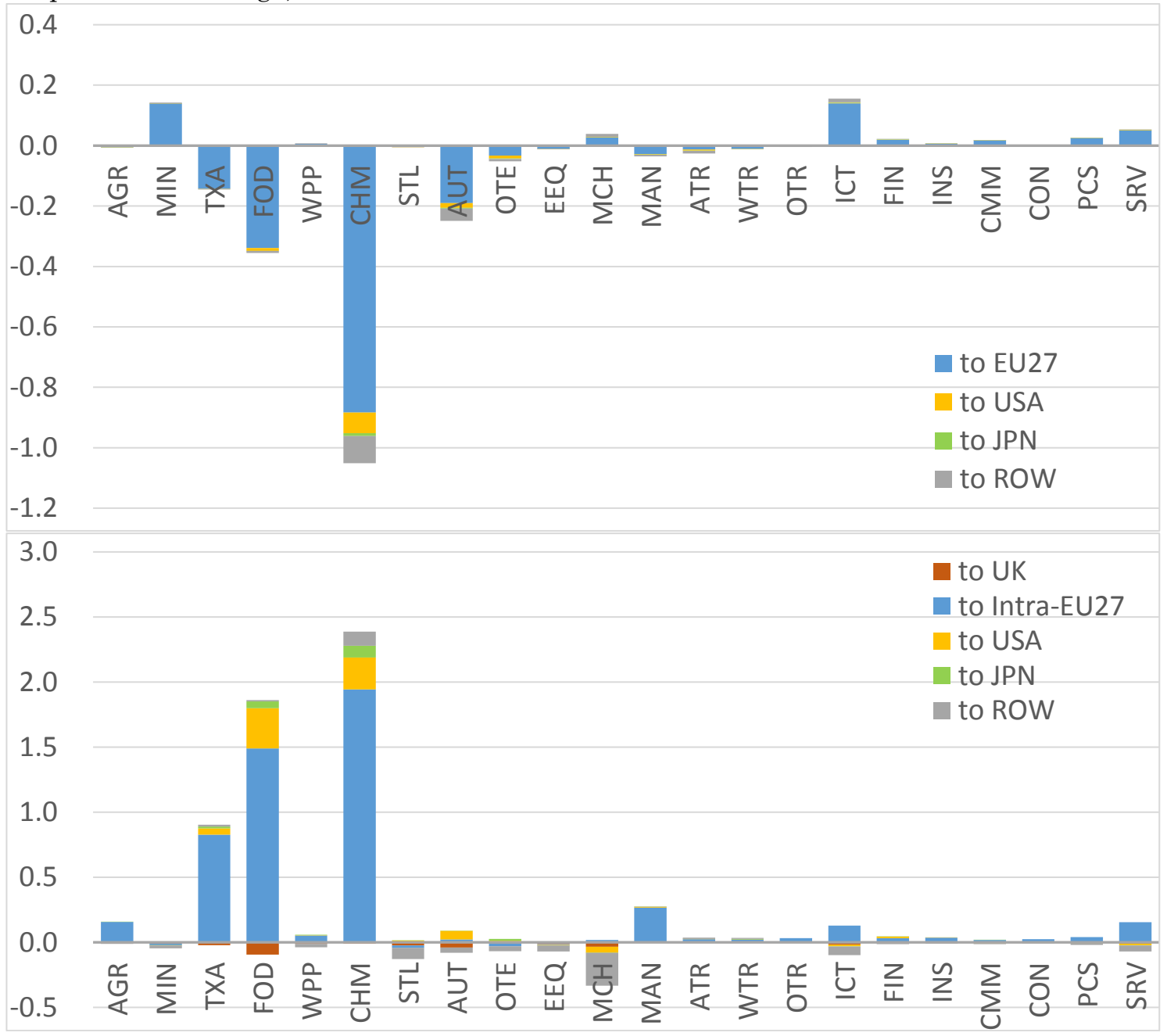

The larger changes in the upper NTB sub-scenario would intensify the export volume change in the four NTB-related scenarios (Figure A.6). Among these, NTB-EU is not as significant a factor for the UK but is for the EU27. Therefore, the choice of sub-scenario more markedly affects EU27 exports than UK exports. 
Figure A.6: Aggregate Export Changes by Scenario Factor with the Upper NTB Sub-scenario [Export Value Change, \% of UK and EU27 GDP]

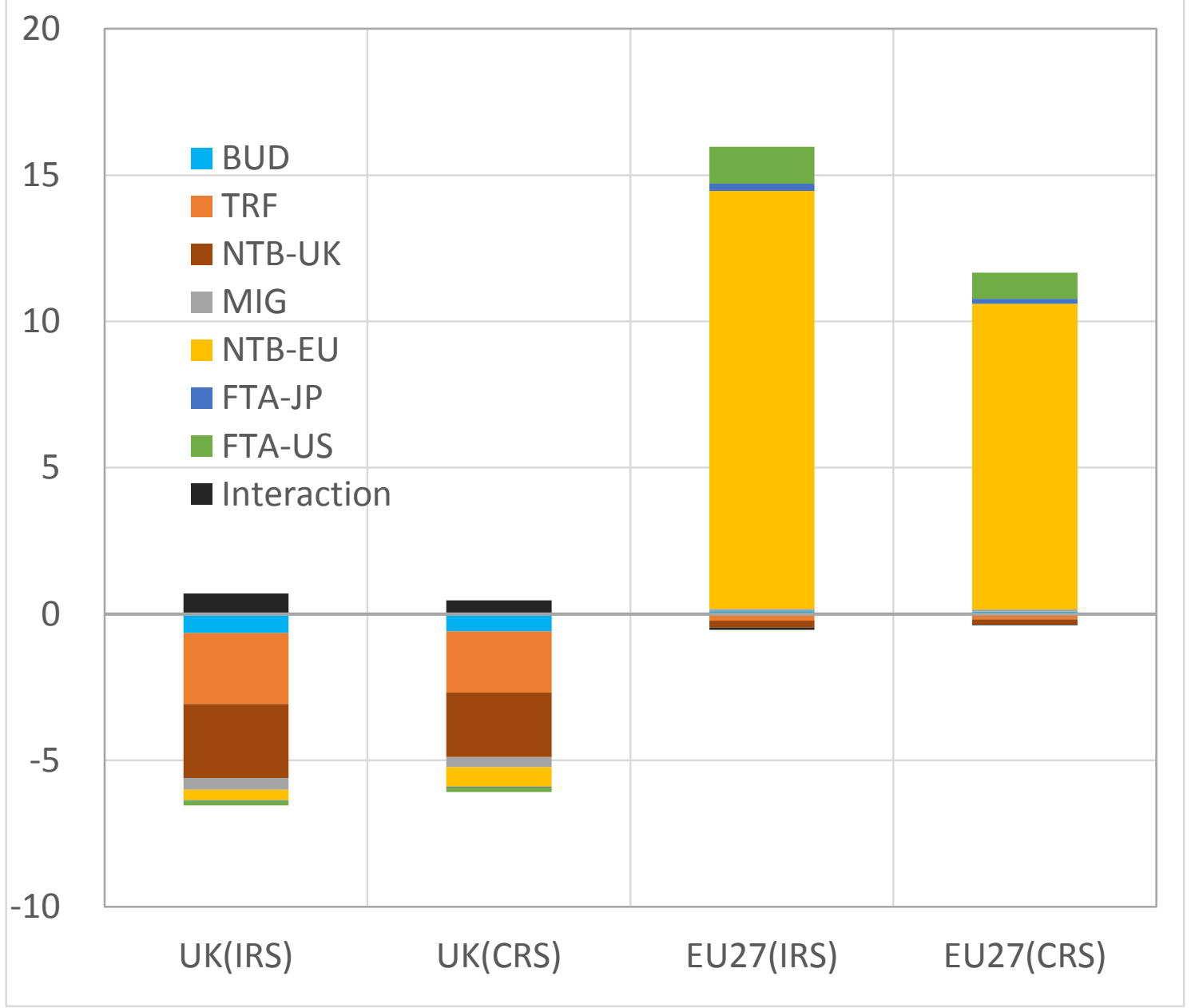

Table A.4: Aggregate Export Changes by Scenario Factor with Alternative NTB Subscenarios and Models

[Export Value Change, \% of UK and EU27 GDP]

\begin{tabular}{|c|c|c|c|c|c|c|c|c|}
\hline & \multicolumn{4}{|c|}{ UK } & \multicolumn{4}{|c|}{ EU27 } \\
\hline & \multicolumn{2}{|c|}{ Lower NTB } & \multicolumn{2}{|c|}{ Upper NTB } & \multicolumn{2}{|c|}{ Lower NTB } & \multicolumn{2}{|c|}{ Upper NTB } \\
\hline & IRS & CRS & IRS & CRS & IRS & CRS & IRS & CRS \\
\hline ALL & -5.05 & -4.70 & -5.83 & -5.61 & 9.30 & 6.94 & 15.42 & 11.28 \\
\hline BUD & -0.65 & -0.59 & $\leftarrow$ & $\leftarrow$ & 0.10 & 0.09 & $\leftarrow$ & $\leftarrow$ \\
\hline TRF & -2.43 & -2.09 & $\leftarrow$ & $\leftarrow$ & -0.22 & -0.17 & $\leftarrow$ & $\leftarrow$ \\
\hline NTB-UK & -1.62 & -1.41 & -2.53 & -2.19 & -0.15 & -0.12 & -0.24 & -0.18 \\
\hline MIG & -0.40 & -0.35 & $\leftarrow$ & $\leftarrow$ & 0.08 & 0.07 & $\leftarrow$ & $\leftarrow$ \\
\hline NTB-EU & -0.27 & -0.42 & -0.36 & -0.67 & 8.46 & 6.32 & 14.28 & 10.44 \\
\hline FTA-JP & -0.02 & -0.02 & -0.03 & -0.03 & 0.20 & 0.14 & 0.25 & 0.18 \\
\hline FTA-US & -0.09 & -0.09 & -0.15 & -0.15 & 0.84 & 0.61 & 1.26 & 0.89 \\
\hline Interaction & 0.42 & 0.28 & 0.70 & 0.47 & -0.02 & -0.00 & -0.08 & -0.03 \\
\hline
\end{tabular}

Notes: Results graphically presented in Figures 4.4 and A.6.

For the UK, the CRS model would predict smaller sectoral value-added changes, particularly in the seven sectors assumed to be IRS sectors in the IRS model (Figure A.7). On 
the EU27 side, the sensitivity of the value-added impacts to model choice is not so straightforward. For example, in the CRS setup, the gains from NTB-EU would be more intense for CHM, while gains or losses would become smaller in most sectors. Gainers and losers are consistently the same for predictions by the two models and larger NTB changes would generally intensify the sectoral value-added changes (Figure A.9). 
Figure A.7: Value-Added Change in the UK (top) and EU27 (bottom), Predicted by a CRS Model with the Lower NTB Sub-scenario

[Value Change, \% of UK and EU27 GDP]

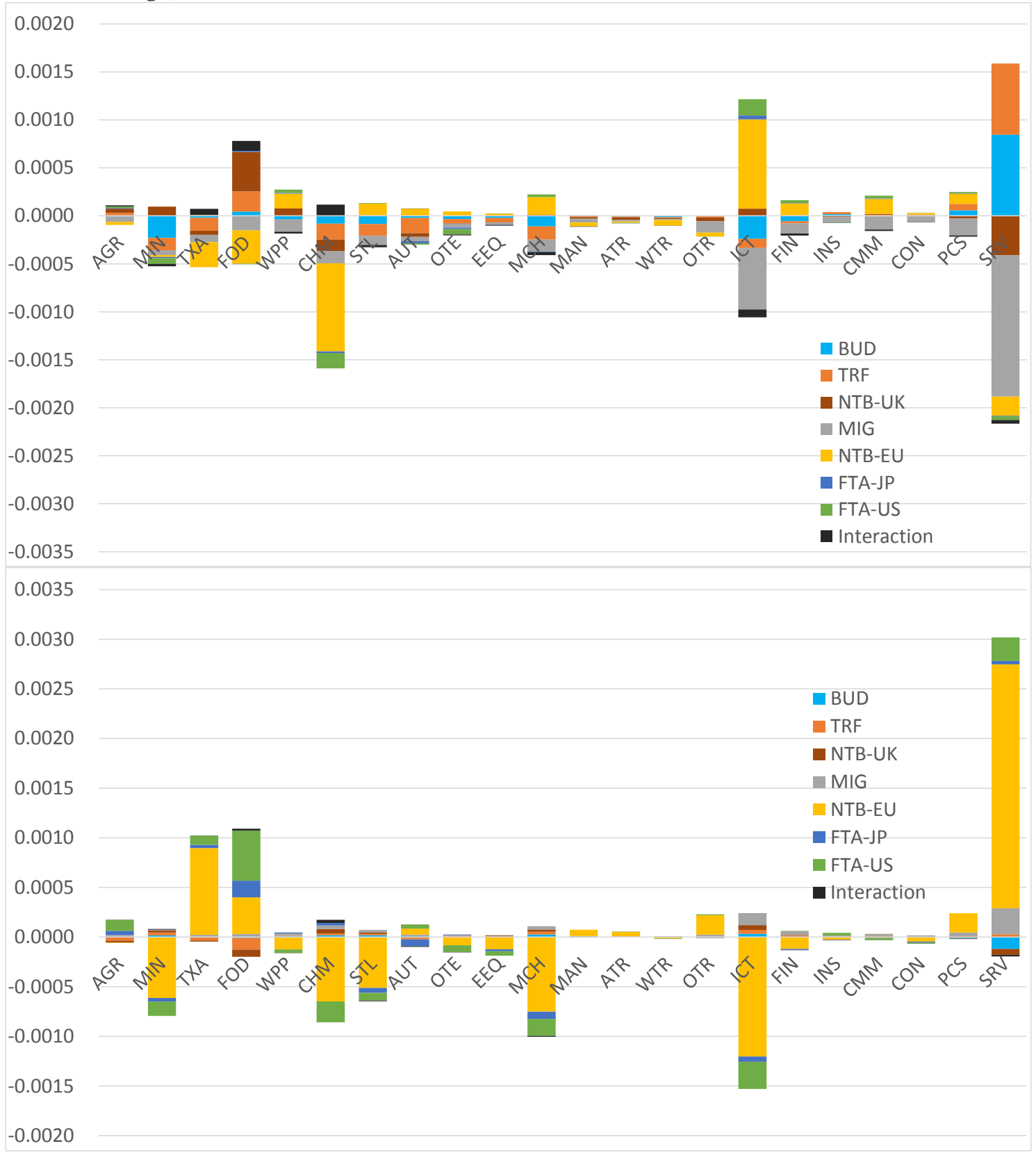


Figure A.8: Value-Added Change in the UK (top) and EU27 (bottom), Predicted by a CRS Model with the Upper NTB Sub-scenario

[Value Change, \% of UK and EU27 GDP]

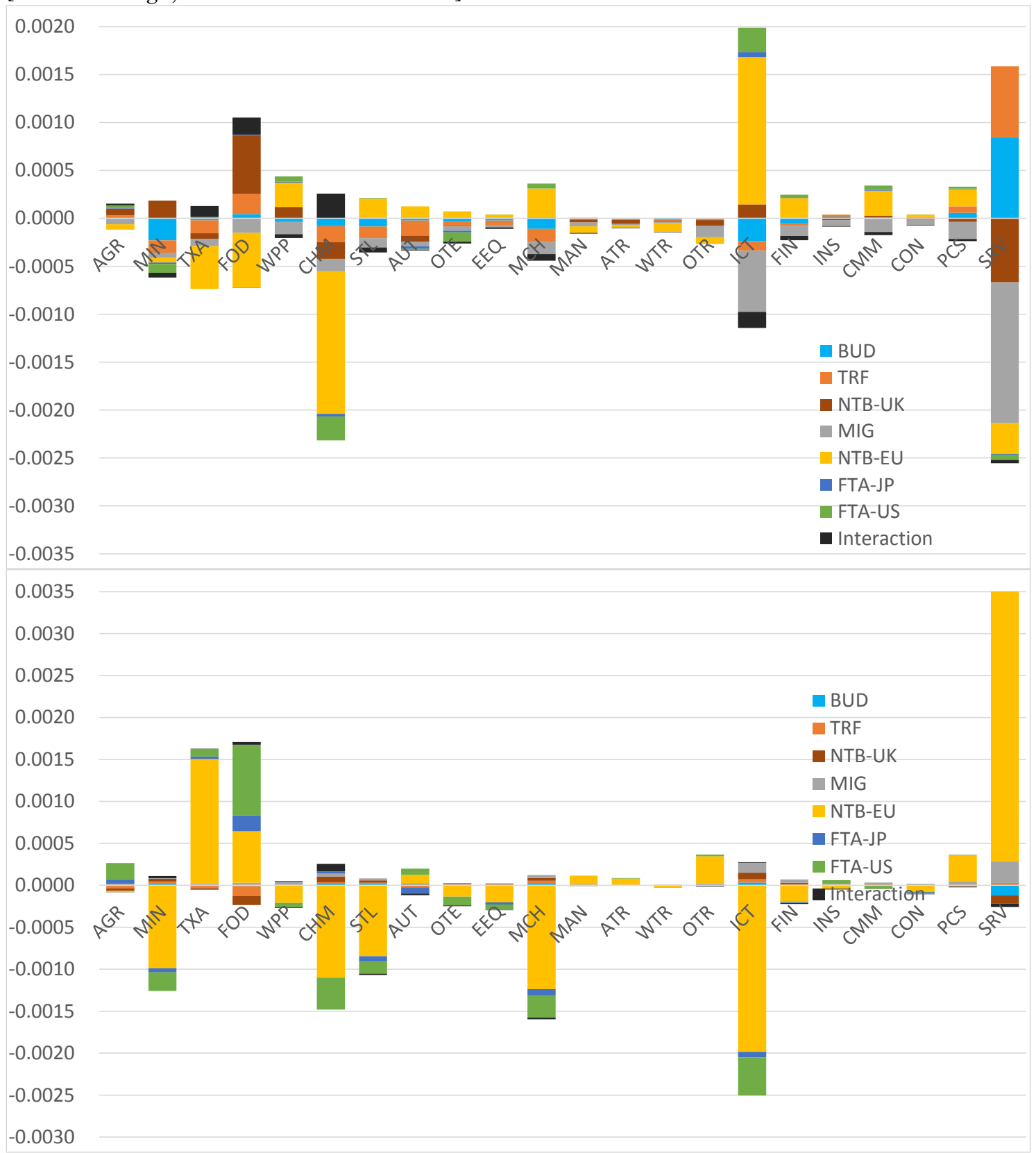


Figure A.9: Value-Added Change in the UK (top) and EU27 (bottom), Predicted by an IRS Model with the Upper NTB Sub-scenario

[Value Change, \% of UK and EU27 GDP]

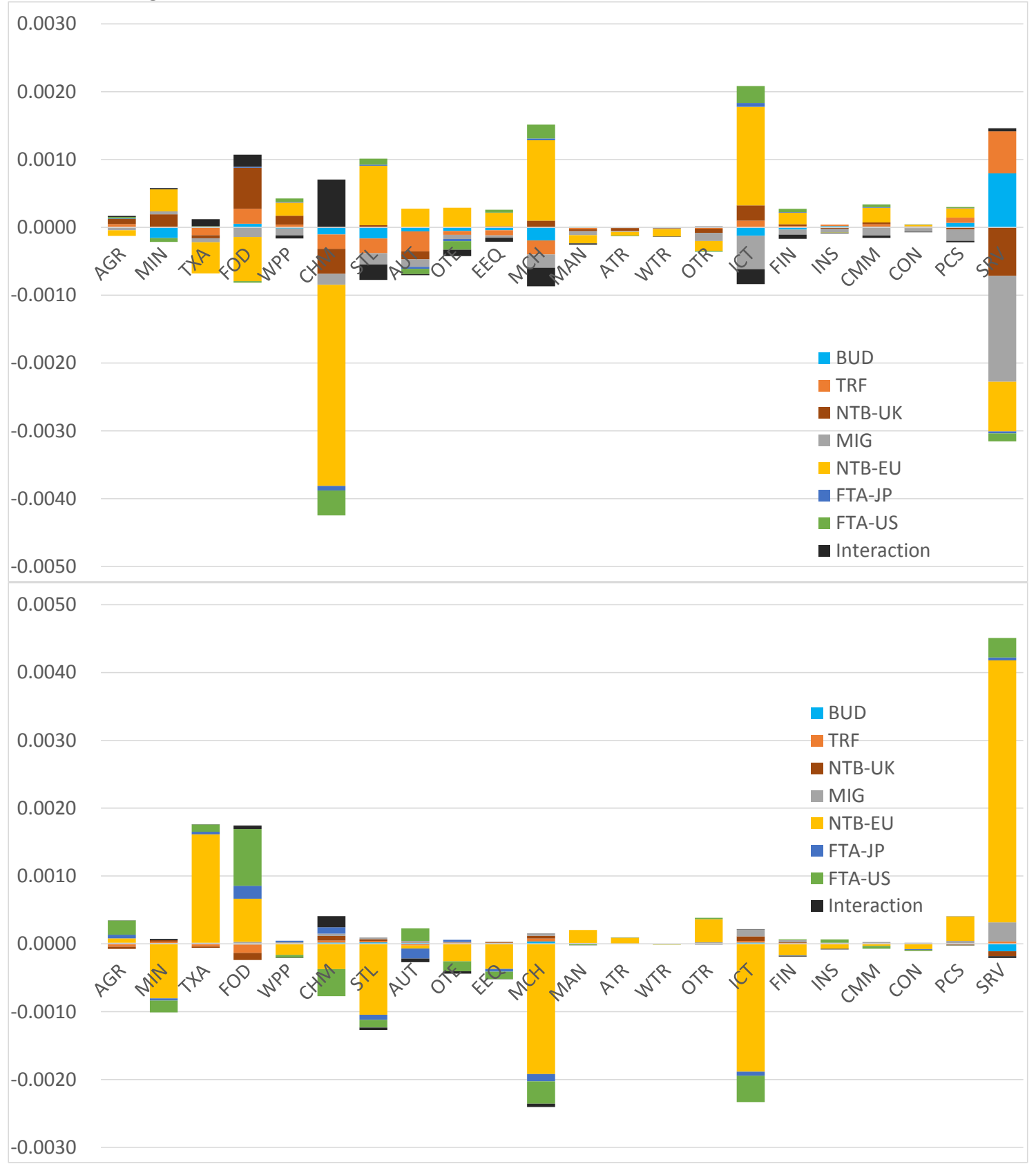

